Article

\title{
Long-Term Development of Urban Agriculture: Resilience and Sustainability of Farmers Facing the Covid-19 Pandemic in Japan
}

\author{
Shingo Yoshida ${ }^{1, *}$ and Hironori Yagi ${ }^{2}$ (1) \\ 1 Policy Research Institute, Ministry of Agriculture, Forestry and Fisheries, Tokyo 100-0013, Japan \\ 2 Department of Agricultural and Resource Economics, Graduate School of Agricultural Life Sciences, \\ The University of Tokyo, Tokyo 113-8657, Japan; ayouken@mail.ecc.u-tokyo.ac.jp \\ * Correspondence: shingo_yoshida610@maff.go.jp; Tel.: +81-3-6737-9612
}

Citation: Yoshida, S.; Yagi, H. Long-Term Development of Urban Agriculture: Resilience and Sustainability of Farmers Facing the Covid-19 Pandemic in Japan. Sustainability 2021, 13, 4316. https:// doi.org/10.3390/su13084316

Academic Editor: Francesco Orsini

Received: 12 March 2021

Accepted: 10 April 2021

Published: 13 April 2021

Publisher's Note: MDPI stays neutral with regard to jurisdictional claims in published maps and institutional affiliations.

Copyright: (c) 2021 by the authors. Licensee MDPI, Basel, Switzerland. This article is an open access article distributed under the terms and conditions of the Creative Commons Attribution (CC BY) license (https:// creativecommons.org/licenses/by/ $4.0 /)$.

\begin{abstract}
The coronavirus disease 2019 (Covid-19) pandemic has forced global food systems to face unprecedented uncertain shocks even in terms of human health. Urban agriculture is expected to be more resilient because of its short supply chain for urban people and diversified farming activities. However, the short-and long-term effects of the Covid-19 pandemic on urban farms remain unclear. This study aims to reveal the conditions for farm resilience to the Covid-19 pandemic in 2020 and the relationship between short-term farm resilience and long-term farm development using data from a survey of 74 farms located in Tokyo. The results are as follows. First, more than half of the sample farms increased their farm sales during this period. This resilience can be called the "persistence" approach. Second, short-term farm resilience and other sustainable farm activities contributed to improving farmers' intentions for long-term farm development and farmland preservation. Third, the most important resilience attributes were the direct marketing, entrepreneurship, and social networks of farmers. We discussed the necessity of building farmers' transformative capabilities for a more resilient urban farming system. These results imply that support to enhance the short-term resilience of urban farms is worth more than the short-term profit of the farms.
\end{abstract}

Keywords: resilience; sustainability; urban agriculture; long-term development; regression analysis; direct marketing; entrepreneurship; social network

\section{Introduction}

\subsection{Covid-19 Pandemic and Food System}

The coronavirus disease 2019 (Covid-19) pandemic affected every aspect of economic and social human activities, thereby causing dysfunction in food systems. According to Savary et al. [1], the effects of the Covid-19 pandemic on six components of food security, such as primary production of food, stability of production, food reserves and stockpiles, physical access to food, economic access to food, and diets, can be classified into three types: short-term (0-3 months), medium-term (3-12 months), and long-term ( 1 year or more). For example, the problems of the primary production of food include a shortage of agricultural labor (short-term), disrupted input supply chains (medium-term), and the disappearance of low-tech farms (long-term). Furthermore, the constraints of physical and economic access to food may pose challenges for farmers who utilize short supply chains. In particular, small-scale farmers are said to be affected by a lack of markets due to the widespread closure of restaurants, farmers' markets, and schools [2]. In the context of these circumstances, Savary et al. added "human health" as a food security driver. Therefore, it is necessary for researchers and policymakers to consider the Covid-19 pandemic not as a one-shot global challenge but as a possible risk to human health in the future and then investigate the effects of the Covid-19 pandemic on global and local food systems. 
However, the effects of the Covid-19 pandemic on farms differ according to country, region, and type of agriculture. For example, a quantitative study on Chinese farms indicated that only $2 \%$ of the sample farms increased their sales during the Covid-19 pandemic in 2020. According to this study, farms in the areas where the incident rate of Covid-19 was high experienced falling sales and rising operating costs [3]. Conversely, a case study on Italian farms that diversified into agritourism demonstrated that most of them exploited the business opportunity that appeared during the Covid-19 pandemic and increased their sales through home-delivery services and online selling of their products [4].

In this context, the question is what effects the Covid-19 pandemic had on agriculture in urban and peri-urban areas that were the Covid-19 epicenters in the world. Generally, studies on farm diversification in developed countries have indicated that the shorter the distance between farms and cities, the greater the tendency for farms to diversify their businesses [5-8]. From the viewpoint of direct marketing to consumers, urban and periurban farmers can consider the social and economic situations caused by the Covid-19 pandemic as growth opportunities. However, strict lockdown and movement restrictions may negatively affect urban and peri-urban agriculture (UPA). Therefore, this study aims to evaluate the consequences of the Covid-19 pandemic on UPA and future prospects for its long-term development in Japan. Furthermore, this paper considers the Covid-19 pandemic as a kind of social and economic shock, and then, it assesses the resilience of UPA to the shock (persistence or adaptation approaches). From this novel resilience viewpoint, this evaluation enables researchers and policymakers to discuss the urban food system's capacity to deal with uncertainties related to public health and its resilience attributes such as short supply chain, farmers' entrepreneurship, and social networks. Moreover, this paper investigates the complementary relationship between resilience and sustainability in terms of long-term farm development.

\subsection{Effects of Covid-19 Pandemic on Urban Agriculture in Japan}

The Covid-19 pandemic has had various negative impacts on agriculture in Japan. A July questionnaire survey in 2020 showed that the diffusion index of agriculture decreased from +6.0 points in 2019 to -25.9 points in the first half of 2020 (Japan Finance Cooperation, July Survey on Agricultural Business Confidence, 2020). The negative score of the diffusion index means that the number of negative farmers, i.e., those affected by the economic downturn, exceeds the number of positive farmers. The reasons for this can be traced through a survey performed within the community of farmers where the following responses were obtained: "fall in production price" (68.4\%), "stop or reduction of marketing channels" $(32.9 \%)$, and "stop or reduction of direct marketing" $(24.2 \%)$. Therefore, problems related to marketing channels were severe for farmers in 2020.

However, in terms of UPA, the Covid-19 pandemic did not necessarily have only negative impacts. According to a questionnaire survey of the Ministry of Agriculture, Forestry, and Fisheries, the percentage of people who thought that the multifunctional roles of UPA became stronger due to the Covid-19 pandemic was 50.2\% (Ministry of Agriculture, Forestry and Fisheries, Online May Survey on Urban Residents' Views on Urban Agriculture, 2020). This suggests that UPA in Japan is appreciated during this period. Generally, it can be said that the sales of local agricultural products in farmers' markets, supermarkets, and garden centers rapidly increased because of the stay-home campaign. Another survey of the Tokyo Metropolitan Government indicates the growing interest of urban people in natural environments in urban settings during this pandemic. The typical answers are as follows: Because of the Covid-19 pandemic, "parks or green spaces are important" $(60.5 \%)$, "the appropriate distance between urbanites and natural environments should be reconsidered" (29.1\%), and "I am interested to use allotment gardens" (23.8\%).

Conversely, the Covid-19 pandemic negatively affected UPA in Japan. Figure 1 shows the weekly average of the number of positive cases per day and the related social conditions in Tokyo. The number of positive cases reached its peak three times: in April and August 2020, and January 2021. The first shock to UPA in Tokyo was the closure of almost all 
elementary schools, junior high schools, and high schools, and the associated suspension of school meals during the spring season. According to a survey by the Ministry of Education, Culture, Sports, Science and Technology, 100\% of public schools in Tokyo and $82 \%$ of private schools in Japan shut down during this period. Urban farmers seemed to suffer from the decreasing demand for school meals, because $95 \%$ of elementary schools and junior high schools in Tokyo were using local agricultural products for school meals.

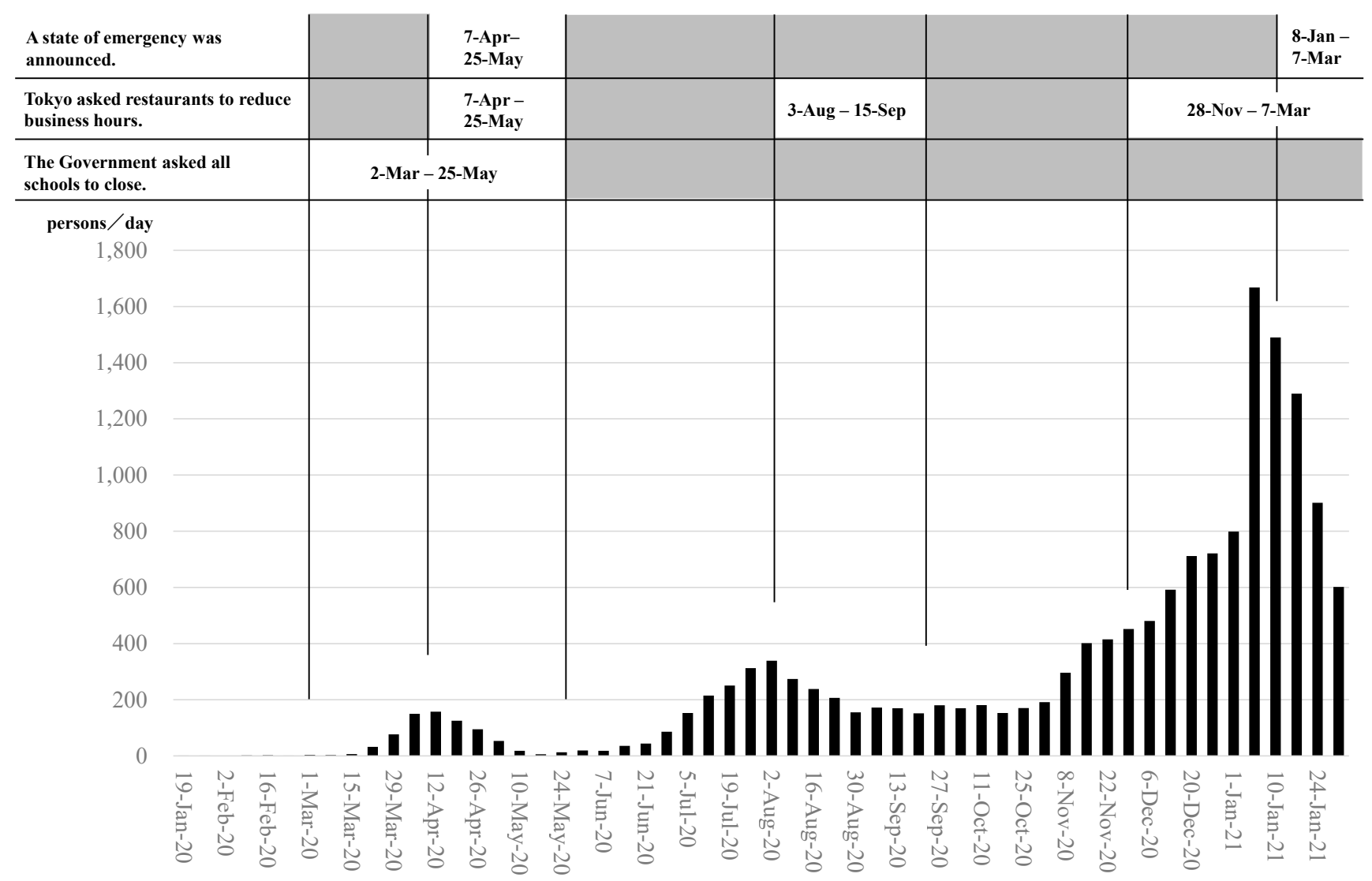

Figure 1. Weekly average of the number of positive cases a day and related social conditions in Tokyo. Note: Data were downloaded via the NHK website (https:/ / www3.nhk.or.jp/news/special/coronavirus/) (accessed on 8 February 2021).

In addition, the Tokyo Metropolitan Government had asked restaurants, bars, and nightclubs to reduce their business hours four times, which spanned approximately seven months in total. As marketing channels to such food-service industries are also important for urban farmers, this economic situation would have had a negative impact on farm performance. Moreover, diverse events and services, such as farming experience services, direct marketing events, and agritourism, were restricted or voluntarily closed during this period.

Considering the aforementioned complex social and economic situations, an empirical and significant question needs to be answered: what effects did Covid-19 pandemic have on the short-term income and long-term farming vision of urban farmers in Japan? Furthermore, as the situations related to Covid-19 are changing every moment at present, the acquisition of correct data on urban farms in 2020 will become increasingly difficult unless we organize information as soon as possible.

\subsection{Farm Resilience and Urban Agriculture}

Academic interest in the importance of resilience of farming systems to social and economic uncertainties, such as the Covid-19 pandemic, is rapidly increasing. In general, resilience is defined as "the capacity of a system to absorb disturbance and reorganize while undergoing change so as to still retain essentially the same function, structure, identity, and 
feedbacks" [9]. Disturbance includes not only drastic changes in the natural environment, such as climate change or earthquakes, but also socio-economic changes such as social value shifts or international trade market fluctuations. Furthermore, these changes affect multiple spatial scales (local, national, and international sites of action) [10]. Thus, the units of resilience analysis differ depending on the research purpose, ranging from individual farms [10] to farming systems [11].

According to the overview of the strategies that farms need to combine, approaches to stresses or shocks at the farm level can be classified into two types: persistence and adaptation [10]. Persistence consists of an exploitation strategy, where the farm takes advantage of successful activities and shifts more resources to these activities, and an absorption strategy, where the farm has sufficient buffer capacity to cope with the crisis. The components of adaptation are adjustment and transformation strategies. The former strategy means that the disturbance requires some adjustment at the farm level, including new production methods, on-farm processing, or direct marketing. The latter strategy requires farms to realign management resources and introduce unconventional activities. Darnhofer also suggested two important aspects of resilience: bounce back and bounce forward [12]. This means that the objectives of resilient thinking are not only to restore the current state to the pre-disaster state and functions but also to transform the farm capacity in accordance with societal changes. It is necessary to determine the possibility of transitions in the way urban farmers do their businesses.

The degree of resilience of urban farmers in Japan should be discussed in advance. First, rapid economic growth from the late 1950s onwards has led to the uneven growth of urban fringe areas, including expansion into large areas of farmland [13,14]. In spite of this harsh environment, many farmers have survived in urban and peri-urban areas; this implies that existing urban farmers are resilient to some extent. Yoshida showed that in the Tokyo metropolitan area, more than $50 \%$ of ploughed fields and rice paddies are located within 2 and $3 \mathrm{~km}$ from densely inhabited districts (DID), respectively [15]. His study also indicated that with a decreasing distance from a DID, urban sprawl had more positive effects on farmland parcel sizes and farm-diversified activities. Indeed, some urban farmers exhibit higher levels of entrepreneurship than other farmers and have responded positively to the pressures of urbanization, such as high taxation, vandalism, and lowquality agricultural infrastructure [16]. In the Tokyo metropolitan area, a few advanced diversified farms with entrepreneurial orientation, social networks, and management capabilities showed more economic and social sustainability than conventional farms [8].

In summary, some urban farmers seem to have demonstrated adaptive or transformative resilience to the rapid and uneven growth of urban areas. However, the shock caused by the Covid-19 pandemic is completely different from the previous development stress. Therefore, it is necessary to ascertain the effectiveness of urban farmers' capacity to accumulate in this unprecedented challenge.

Furthermore, the most important objective for UPA is not the short-term resilience of urban farmers to the Covid-19 pandemic but the long-term development of a farming system as a whole. It is expressed that "sustainability is a concept complementary to resilience and refers to the adequate performance of all system functions across the environmental, economic, and social domains" $[17,18]$. However, a trade-off between resilience and sustainability can be assumed because the stability caused by sustainable activities may inhibit the resilience capability building that enables urban farmers to dynamically transform themselves. Then, the relationship between resilience and sustainability is an empirical question.

The multifunctionality of sustainable urban agriculture is expected to solve various urban problems. Many studies suggest its social functions (education, social cohesion, job creation, human health, and community development) and its environmental functions (increasing ecosystem services and efficient use of energy and resources) [19-24]. Moreover, some studies directly relate urban agriculture to sustainable or resilient cities $[25,26]$. 
Empirical studies on the multifunctionality of urban agriculture are also increasing. First, the potential of urban agriculture for food production has been evaluated [27-29]. However, the motivations of participants in urban farming are not only fresh produce but also social cohesion and money saving [30]. Farming participation is associated with the promotion of social involvement [31,32] and the promotion of human physical and mental health $[33,34]$. In Japan, Soga et al. suggested that the participants in allotment gardens increased their social activities [35], whereas Harada et al. revealed that participants in farming experience farms run by professional urban farmers show more improvement in physical and mental health indicators than the participants in ordinal allotment gardens [36]. This evidence indicates that the long-term development of urban farms contributes to sustainable development goals in cities [20].

However, sustainability is rather based on "equilibrium thinking" that emphasizes predictability and stability [10]. In unpredictable and uncertain environments, "resilience thinking" [37] that emphasizes dynamic processes of adaptation and transformation of farming systems is needed for a long-term development that is not based on equilibrium thinking [10]. Consequently, the outcome of farmers' behaviour toward the Covid-19 pandemic certainly affects more long-term vision for farm development. The understanding of this relationship among resilience, sustainability, and long-term development will enable researchers and policymakers to discuss the impact of the Covid-19 pandemic on UPA.

\subsection{Attributes of Farm Resilience}

First, one of the resilience attributes emphasized in previous literature is farm diversification $[12,38,39]$. Based on interviews with dairy farmers or organic farmers, functions of farm diversification are not only economies of scope and risk reduction but also acquisitions of management skills and knowledge as well as the enlargement of social networks. For example, organic farmers in Austria identified or created niches for marketing their products, thus acquiring knowledge through social learning and experimentations [39]. Another study demonstrated that $30 \%$ of farmers who participated in workshops diversified into other activities on their farms as a risk-management strategy; these farmers believed that diversification was an effective risk management strategy for the next 20 years [40]. According to a comprehensive literature review on farmers' motivation for farm diversification, although most farmers diversify their business for risk reduction and resource utilisation, some farmers diversify to exploit market opportunities [8]. Consequently, the effects of farm diversification are functionally diverse, and many of them seem to contribute to farm resilience.

Second, the role of farmers as decision-makers is emphasized by Darnhofer et al. [10]. They suggest the importance of "how a farmer perceives and conceptualizes the potential and limits of his or her farm, the risks emanating from economic, social, or ecological changes, and the options that he or she can employ to face them" [10]. The cognitive abilities of farmers are thought to be related to entrepreneurship. Entrepreneurship is the process by which opportunities to create future goods and services are discovered, evaluated, and exploited [41]. The first rationale to consider entrepreneurship as a resilience attribute is that entrepreneurship strongly affects long-term firm performance [42]. Second, the effectiveness of entrepreneurship increases if firms face environmental hostility [43]. Third, the innovative performance of firms is improved by entrepreneurship [44-47]. Fourth, entrepreneurship plays a role in developing absorptive capability [44] and exploratory capability [48], which are related to the learning capacity of firms. Therefore, in the case of family farms, entrepreneurial farm managers in severe business conditions such as the Covid-19 pandemic should have significant impacts on farm resilience by seeking market opportunities and drastically transforming their business models.

Lastly, social networks are frequently indicated as resilience attributes. It has been suggested that building a strong social network contributes to acquiring accurate information and a complete set of options for change [10]. According to a paper that discusses the resilience of communities to natural disasters, social networks are important for combining 
different types of knowledge [49]. Analyses of farming systems, including individual farms, indicate that cooperatives and producers' organizations are considered effective measures for enhancing the transformability by various stakeholders [18], and farmers who participated in workshops also acknowledge the significance of peer-to-peer learning and knowledge networks for building resilience capabilities $[40,50]$. Moreover, farmers social networks are considered to have a potential impact on farm performance because they can be a source of business opportunities [51,52] and external management resources such as advice [53-55]. These results correspond to the fact that the analytical framework for the resilience of farming systems can be structured with the inclusion of networks for collaboration opportunities, stakeholder management, and an open attitude toward innovation, as resilience attributes $[11,56]$.

\subsection{Objectives}

In view of the aforementioned discussion, the purposes of this study are summarized as follows: The first objective is to understand the impact of the Covid-19 pandemic on urban and peri-urban agriculture (UPA) in Japan. This investigation answers what type of strategies individual urban farms have adapted to be resilient to the Covid-19 pandemic. Therefore, we ascertained the types of resilience capabilities of urban farmers during the Covid-19 pandemic. Second, this study clarifies the relationship among farm resilience, farm actions for social and environmental sustainability, and long-term farm vision. Third, the effects of resilience attributes, such as farm diversification, entrepreneurship, and social networks, on resilience building are to be investigated. Then, we discuss the comprehensive conditions for the long-term development of UPA in Japan.

\section{Methodology}

\subsection{Conceptual Framework}

We apply Meuwissen's framework to assess the resilience of farming systems to the conceptual framework of this study [57]. We selected this framework because it is based on much of the theoretical and empirical novel research conducted by SURE-Farm project (full title 'Towards SUstainable and REsilient EU FARMing systems'). The applicability of this framework to the specific farming system is sufficient. The framework consists of five steps: (1) "Resilience of what?" (farming systems), (2) "Resilience to what?" (challenges), (3) "Resilience for what purpose?" (functions), (4) "What resilience capabilities?" (resilience capabilities), and (5) "What enhances resilience?" (resilience attributes).

Figure 2 illustrates the conceptual framework of this study. First, the targeted farming system includes individual urban farmers in Tokyo. Generally, these farmers are highly independent of each other. Thus, it is difficult to consider UPA as an integrated farming system. Second, the challenge faced by urban farmers is the Covid-19 pandemic. This pandemic is a shock to the socio-economic activities and public health of human beings. Third, the short-term objective of urban farmers is to maintain the status quo or increase their sales during the pandemic. Moreover, this short-term goal may contribute to a more long-term farm vision for development. Fourth, the types of resilience capabilities, persistence, or adaptation should be clarified. The difference between the two capabilities is whether significant changes are followed by resilience. In short, adaptation means that urban farmers proactively change their crops, farming methods, marketing channels, and business models. Lastly, this study defines the resilience attributes that significantly affect resilience capabilities such as direct marketing practices, entrepreneurship, and social network of farmers. 


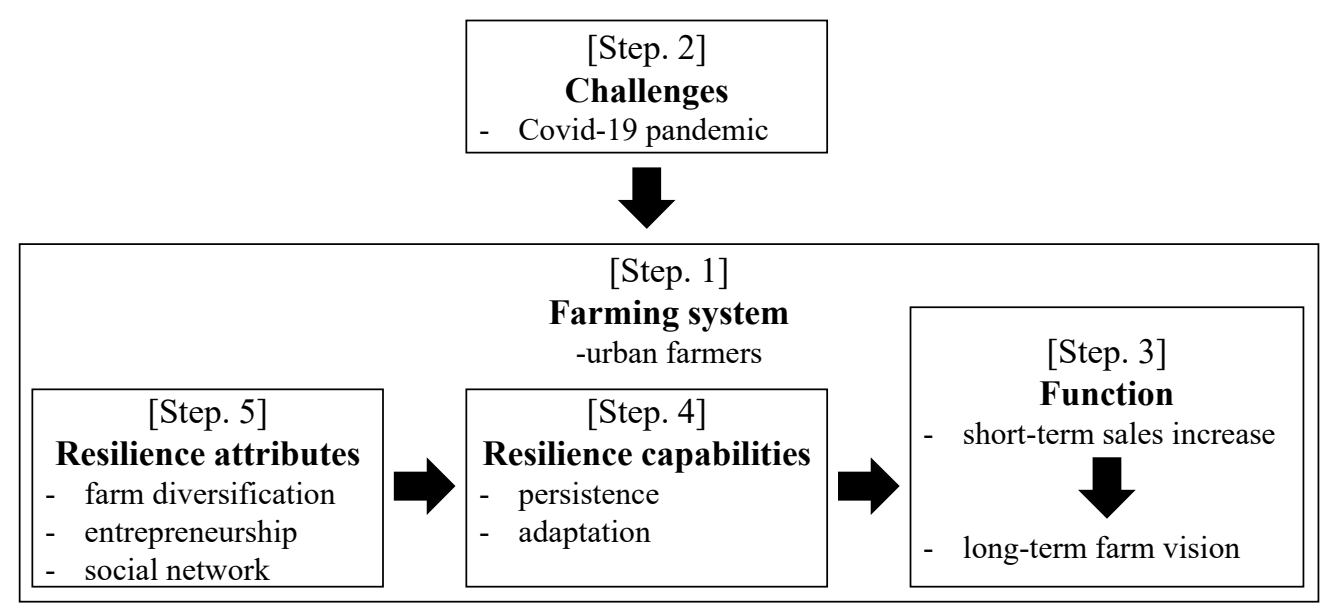

Figure 2. Conceptual framework.

\subsection{Analytical Framework}

The analysis uses data from a web survey of 74 urban farmers located in Tokyo. This survey was distributed to farmers via e-mail and social network services from the 16 December 2020 to the 31 January 2021. Snowball sampling was used as the methodology. The survey administration software was Google Forms. According to the Census of Agriculture and Forestry in 2015, the number of farmers in Tokyo is 6023 (including 482 farmers who lived on remote islands). Although the sample size is relatively small, the answers cover farmers from 10 of the 14 farmers' cooperatives in Tokyo. This implies that the locational bias should be small.

To analyze the consequences of the Covid-19 pandemic on urban farmers' sales, the originality of this study is that farmers are asked to provide information, in every quarter, regarding their sales in 2019, and the year-over-year change rate of sales in 2020. Using these data, we can calculate the number of farms that increase (or decrease) their sales for each period and then calculate the average total sales change in 2020. This study defines the farms whose sales in 2020 have increased from 2019 as "highly resilient farms", because this sales change can be considered to demonstrate the farm's short-term resilience to Covid-19 pandemic. Conversely, we define no-sales-change farms as "middle-resilient farms" and sales-decreasing farms as "less resilient farms".

This study focuses on farmers' intentions to develop farm size as a long-term farm vision. A 3-point scale in a question is used to measure farmers' 10-years-after intention: 1 = downsizing, 2 = status quo, and $3=$ scaling up. Furthermore, four questions on farmland are used to understand the relationship between long-term farm vision and farmland preservation, because the growing scarcity of farmland in urban areas potentially threatens the sustainability of UPA today.

Direct marketing is one of the resilience attributes hypothesized to affect sales changes. This study examines the largest marketing channels of each farm. Marketing channels such as farmers' markets and farm gate sales (manned or unmanned) are classified as direct marketing channels. In addition, other channels such as sales to the wholesale market and sales to the retailer are referred to as mass marketing in this study.

In general, farmers' entrepreneurship can be measured using entrepreneurial orientation. The entrepreneurial orientation (EO) of individual farmers can be assessed in terms of their innovativeness, risk-taking, and proactivity [58]. This study included two questions regarding each indicator. Based on Covin and Slevin [59], a 5-point Likert scale was used to measure which of the two paired contrasting statements most closely matched a farmer's view. The higher the point, the more entrepreneurial the farmer. EO was measured as the sum of responses to six questions.

The social networks of farmers are measured using the questions of whether 10 categories of entities have been supportive for farmers during the Covid-19 pandemic. A 
5-point Likert scale from 1 = not supportive to 5 = greatly supportive is used, and then, the social network score is measured as the sum of responses to ten questions.

Lastly, the sustainability of a farm is assessed by its proactiveness to corporate social responsibility (CSR). CSR activity is defined as "actions that appear to further some social good, beyond the interests of the firm and that which is required by law" [60] or as "firm behaviors that are not mandated by law and are designed to benefit one or more social stakeholders". The term "social stakeholder" includes the physical environment [61]. With reference to previous literature on farm sustainability [62-64], eight indicators related to social sustainability and environmental sustainability were assessed using a 3-point Likert scale: $1=$ not at all proactive, $3=$ more proactive than other farmers. As in previous studies, we distinguish external social sustainability from internal social sustainability. These eight indicators are then summed up to create a social and environmental sustainability index (SESI).

Parametric and nonparametric statistical analyses were performed in this study. Fisher's exact test and pairwise comparisons of the Wilcoxon rank-sum test can be applied to nominal or ordinal variables. However, it is difficult to control the effects of other fundamental factors, such as farm size, farm location, and management skills. Thus, regression analysis was applied to test the hypotheses. The dependent variables are the resilience type, social and environmental sustainability index (SESI), and long-term farm vision. As resilience type and long-term farm vision are ordinal variables, the ordinal logit model is used for estimation. Conversely, ordinary least squares (OLS), which employs continuous variables as a dependent variable, is applied to the SESI model. The control variables are as follows: logarithm of sales in 2019, farmland size, population density of cities where each farmer lives, and management capabilities. Management capabilities include the skills of production, accounting, marketing, and human resource management.

\section{Results}

\subsection{Description of Sample Farms}

First, we summarize the characteristics of the sample farms. As shown in Figure 3, vegetable farms (on an open field or in a greenhouse) were the most frequent $(74.3 \%$ in total). The sample is slightly biased to vegetable farms because the proportion of the vegetable farms in Tokyo is 57\% (the Census of Agriculture and Forestry in 2015). However, there are a few other types of farms in the sample, such as mixed farms $(8.1 \%)$ and dairy farms (6.6\%). Figure 4 illustrates the percentage of farms according to farmland size. Of the sample farms, 31.5\% had 50a-99a (a (are): $10^{2} \mathrm{~m}^{2}$ ) farmland, and $23.3 \%$ had less than $30 \mathrm{a}$ farmland. Whereas there are small urban farms, $26.3 \%$ of sample farms have more than 1 ha of farmland. According to the distributions of farms in Tokyo, the size of the farmland of the sample farms is not so much biased.

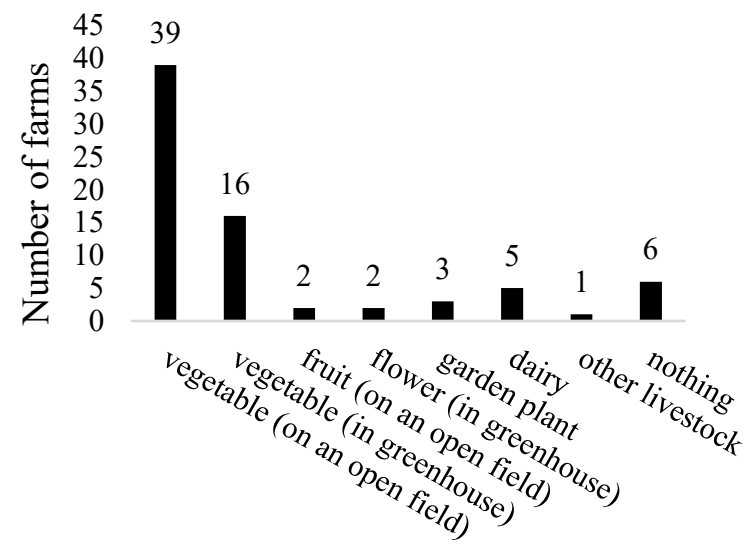

Figure 3. Number of sample farms. Note: Farmers answered a production type that accounts for two-thirds of total farm sales; "nothing" means none of the production types is less than two-thirds of total farm sales. 


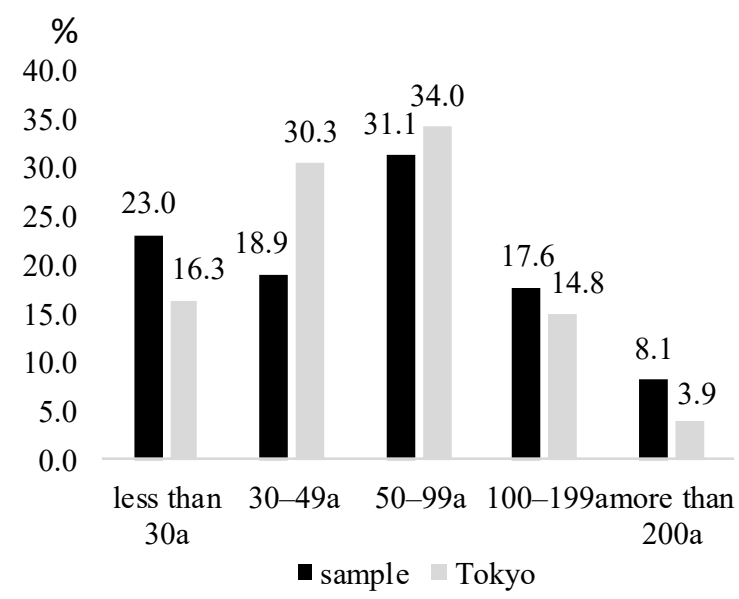

Figure 4. Percentages of farms by farmland size. Note: a (are) $=10^{2} \mathrm{~m}^{2}$. "Tokyo" is a total farm population in Tokyo from the Census of Agriculture and Forestry in 2015.

Regarding farm sales in 2019, as shown in Figure 5, 20.3\% of sample farms' sales and $5.2 \%$ of them in Tokyo are more than 10 million yen. This means that the sample is highly biased to large-sales farms because of the snowball sampling. Figure 6 shows the population density at which each farm is located. Most of the sample farms are located in areas with a population density of more than 5000 persons $/ \mathrm{km}^{2}$. As the population density of Tokyo is 6168 persons $/ \mathrm{km}^{2}$, the sample farms are located in relatively high-density areas in Tokyo. According to these results, the business size of sample farms and farm locations seem to be evenly distributed, and the sampling bias should be small.

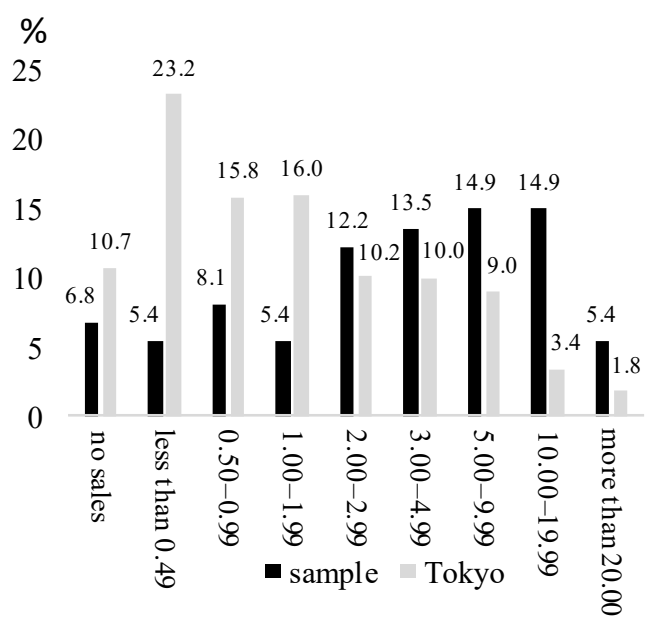

Figure 5. Percentages of farms by farm sales in 2019. Note: "Tokyo" is a total farm population in Tokyo from the Census of Agriculture and Forestry in 2015.

Figures 7 and 8 show the rate of farms by the first largest marketing channel (1st channel) and the second largest marketing channel (2nd channel), respectively. Figure 7 illustrates that as the 1 st channel, $28.4 \%$ of the samples choose farmers' markets, and $32.5 \%$ choose farm gate sales (manned or unmanned). This means that direct marketing is the most popular diversification strategy for sample farms. Conversely, $24.4 \%$ sell their products to mass marketing channels (wholesale market and sales to retailers). As seen in Figure 8, although direct marketing channels are still popular, other diverse channels such as sales to school meals or sales to restaurants are common as the 2 nd channel. 


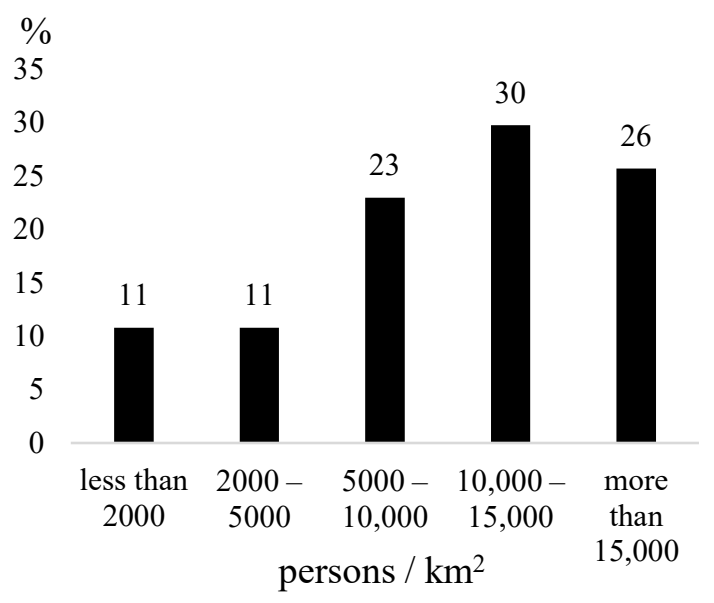

Figure 6. Percentages of farms by population density. Note: The population density of each city in Tokyo is used.

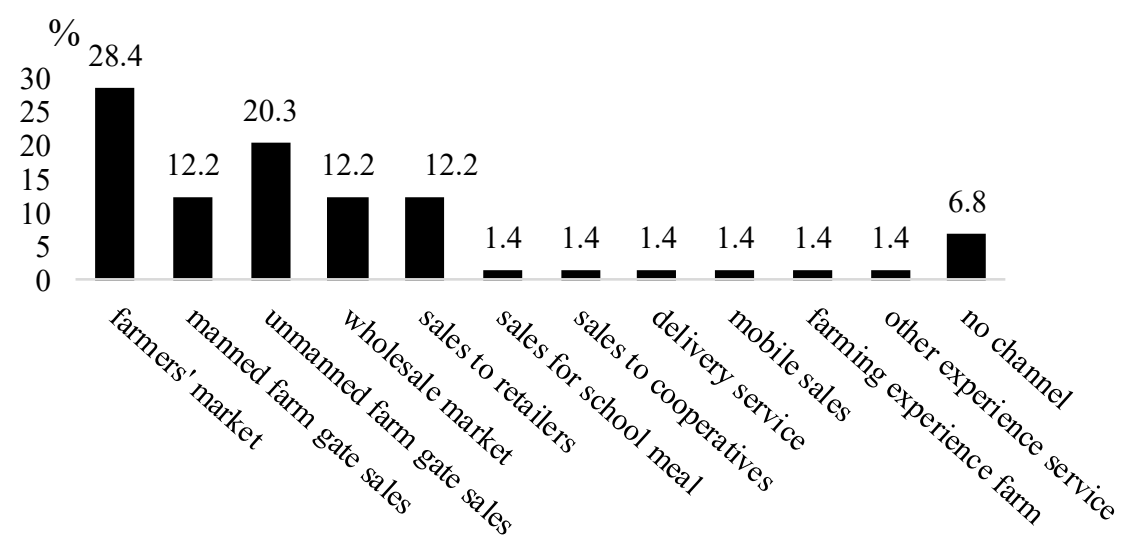

Figure 7. Percentages of farms by the first largest marketing channel (1st channel).

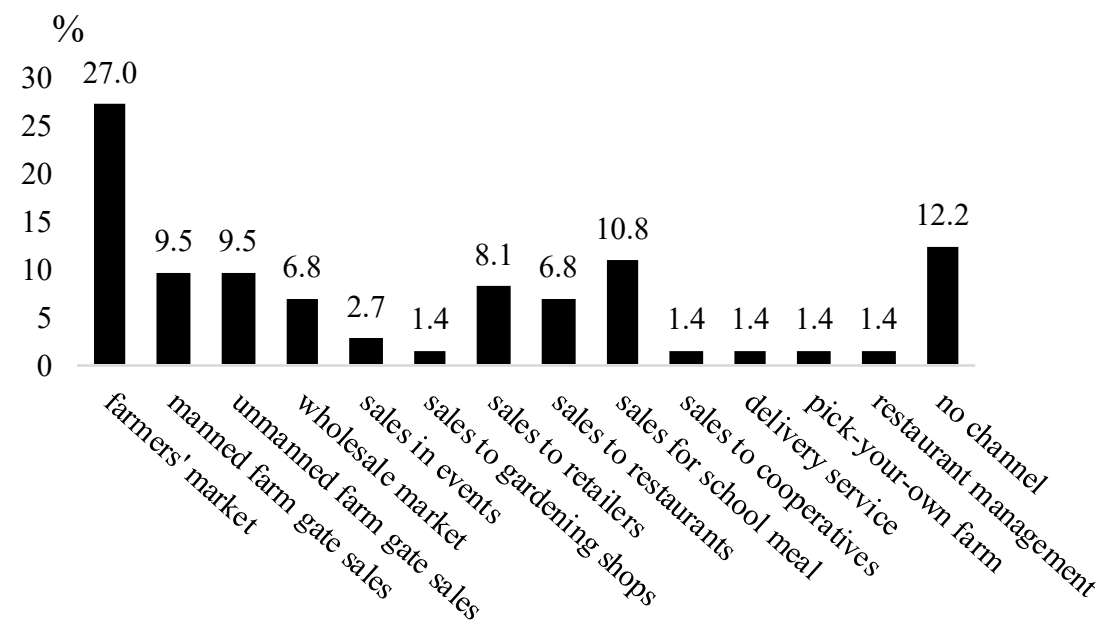

Figure 8. Percentages of farms by the second largest marketing channel (2nd channel).

\subsection{Effects of Covid-19 Pandemic and Resilience Capacity}

In this section, we describe the transitions in farm sales and the factors influencing sales changes in 2020. Figure 9 shows the percentages of farms by year-over-year sales change (increase, no change, or decrease) of the 1st and 2nd channels in every quarter. The results of "no change" are omitted in the figure. Most importantly, the percentages of sample farms who answered that they increased their sales in both the 1st and the 2nd 
channels compared to sales in 2019 were higher than the percentage of those who decreased their sales from January to September. This suggests that in 2020, a large number of sample farms experienced farm sales increase during the Covid-19 pandemic. Conversely, the rate of sales-increasing farms dropped sharply from October to December 2020. In brief, whereas the trend of the sales increase was evident for urban farmers until September, this trend did not continue until the end of 2020.

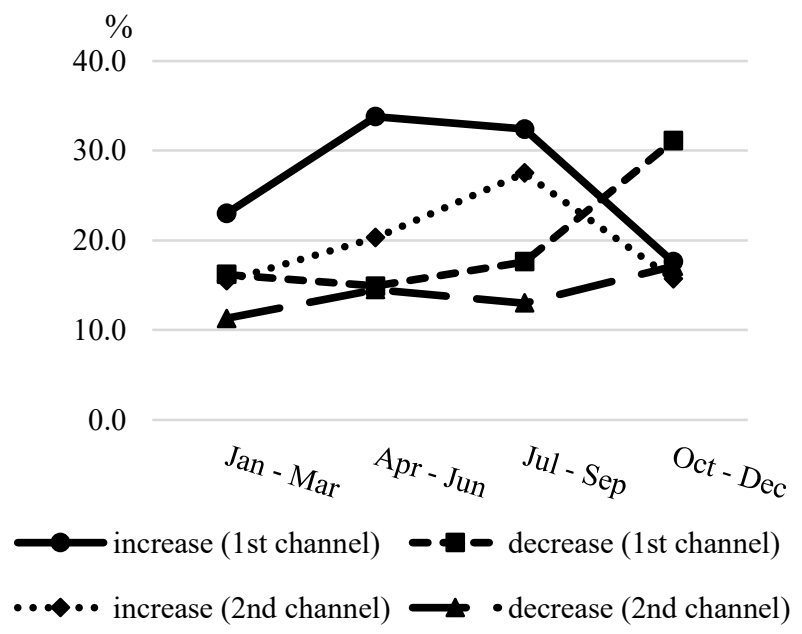

\begin{tabular}{c|c|cccc}
\hline \multirow{2}{*}{$\begin{array}{c}\text { Marketing } \\
\text { channels }\end{array}$} & \multirow{2}{*}{$\begin{array}{c}\text { Change of } \\
\text { sales }\end{array}$} & \multicolumn{4}{|c}{ \% of farms } \\
\cline { 3 - 6 } & & $\begin{array}{c}\text { Jan- } \\
\text { Mar }\end{array}$ & $\begin{array}{c}\text { Apr- } \\
\text { Jun }\end{array}$ & $\begin{array}{c}\text { Jul- } \\
\text { Sep }\end{array}$ & $\begin{array}{c}\text { Oct- } \\
\text { Dec }\end{array}$ \\
\hline \multirow{2}{*}{1 st } & Increase & 23.0 & 33.8 & 32.4 & 17.6 \\
& Decrease & 16.2 & 14.9 & 17.6 & 31.1 \\
\hline \multirow{2}{*}{ 2nd } & Increase & 15.5 & 20.3 & 27.5 & 15.7 \\
& Decrease & 11.3 & 14.5 & 13.0 & 17.1 \\
\hline
\end{tabular}

Figure 9. Percentages of farms by sales change in every quarter in 2020. Note: The questionnaire asked farms to provide details regarding their year-over-year change rate of sales in every quarter in 2020 . Then, we summarized the percentages of farms classified into three: increase farms, decrease farms, and status-quo farms.

Then, we can calculate the total sales changes in 2020 compared to 2019 . As seen in Table 1, the number of highly resilient farms that increase their total sales in 2020 is more than the number of less and middle-resilient farms. Surprisingly, during the Covid-19 pandemic, $41.8 \%$ of the sample farms showed bounce-forward resilience. Moreover, with regard to the average sales changes in 2020 by resilience type, whereas the average sales change of the highly resilient farms is $+662,000$ yen/year, that of the less resilient farms is $-1,045,000$ yen/year. The sales decline of the less resilient farms is much larger than the sales increase of the highly resilient farms. The average deficit of the 1st channel is large for less resilient farms. In total, the average sales change of all farms in 2020 is 9000 yen/year; that is, the Covid-19 pandemic, on average, possibly had almost no effect on sample farms in UPA in Tokyo.

Table 1. Average sales changes in 2020 by resilience type.

\begin{tabular}{|c|c|c|c|c|}
\hline \multirow{2}{*}{$\begin{array}{c}\text { Short-Term } \\
\text { Resilience Type }\end{array}$} & \multirow{2}{*}{$\begin{array}{l}\text { Sample } \\
\text { Size }\end{array}$} & \multirow{2}{*}{$\begin{array}{c}\text { Average Sales } \\
\text { Changes } \\
\text { (yen/year) }\end{array}$} & \multicolumn{2}{|c|}{ By Marketing Channel Types } \\
\hline & & & $\begin{array}{c}\text { 1st Channel } \\
\text { (yen/year) }\end{array}$ & $\begin{array}{c}\text { 2nd Channel } \\
\text { (yen/year) }\end{array}$ \\
\hline Highly resilient farms & 31 & 662,000 & 416,000 & 273,000 \\
\hline Less resilient farms & 19 & $-1,045,000$ & $-932,000$ & $-134,000$ \\
\hline Middle-resilient farms & 24 & 0 & 0 & 0 \\
\hline total & 74 & 9000 & $-65,000$ & 81,000 \\
\hline
\end{tabular}

Note: After summing up sales changes in every quarter in 2020, average sales changes were calculated by resilience types.

The results in Table 1 indicate that the 1st channel affects farm resilience the most during this period. Figure 10 demonstrates the percentage of the 1st channel by resilience type. Almost $70 \%$ of highly resilient farms use direct marketing channels. Conversely, $47 \%$ of the less resilient farms sell to the mass market (wholesale market and sales to retailers). In short, farm resilience to the Covid-19 pandemic may be partly affected by farm 
diversification into direct marketing. In addition, $21 \%$ of the middle-resilient farms select "no channel". This suggests that the middle-resilient farms consist of non-sales farms.

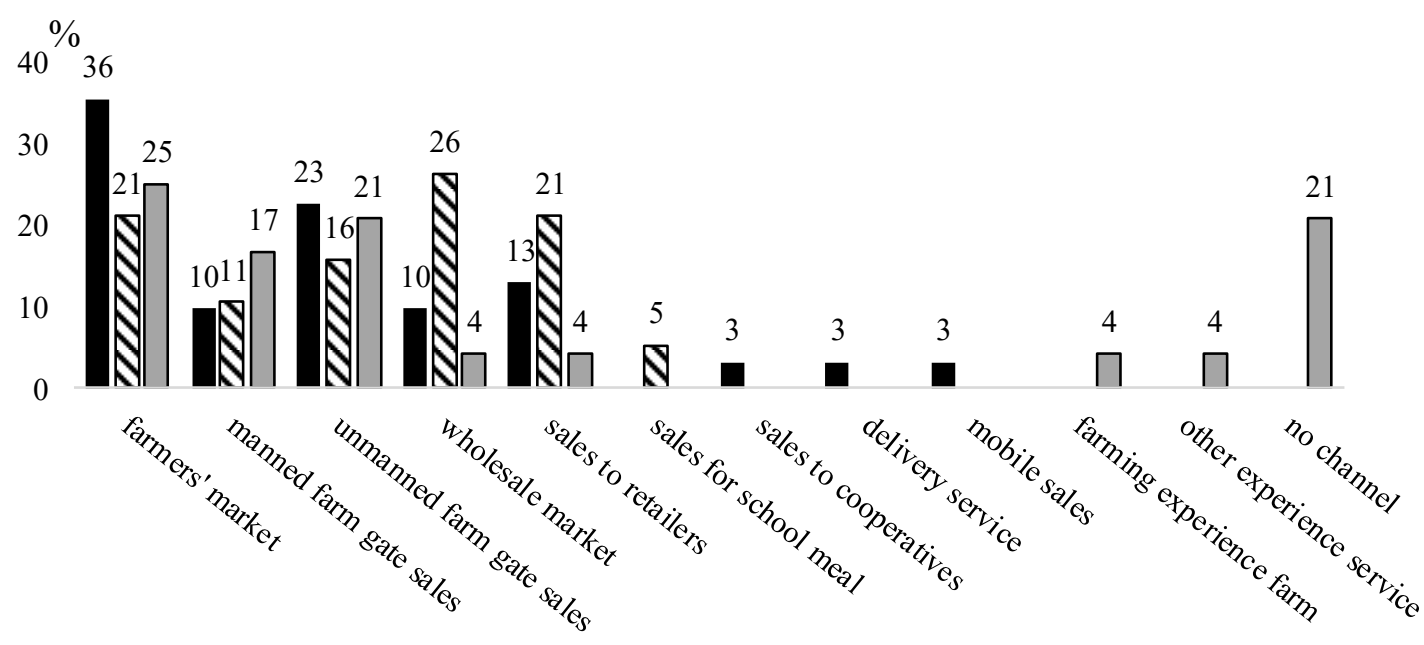

- Highly resilient farms $\mathbf{D}$ Less resilient farms $\quad \square$ Middle-resilient farms

Figure 10. Percentage of first marketing channel by resilience type.

The reasons for the increase in sales and sales decrease are illustrated in Table 2. As seen in Table 2, reasons such as "customer increase at farm gate" $(41.9 \%)$ and "customer increase in farmers' markets" (32.3\%) are frequently indicated by the highly resilient farms. This result reinforces our hypothesis regarding the relationship between direct marketing and farm resilience. In addition, "increased production" (29.0\%) is also an important factor; that is, it is possible that resilient farms have tried to increase their production for growing customers during this period.

Table 2. Percentages under each reason for sales increase and decrease.

\begin{tabular}{|c|c|c|c|c|c|c|c|c|c|}
\hline \multirow{3}{*}{$\begin{array}{l}\text { Highly } \\
\text { resilient } \\
\text { farms } \\
(n=31)\end{array}$} & \multicolumn{9}{|c|}{ Reasons for sales increase (multiple answers) (\%) } \\
\hline & $\begin{array}{c}\text { Customer } \\
\text { increase in } \\
\text { farmers' } \\
\text { markets }\end{array}$ & $\begin{array}{l}\text { Customer } \\
\text { increase at } \\
\text { farm gate }\end{array}$ & $\begin{array}{c}\text { Sales } \\
\text { increase } \\
\text { for retailers }\end{array}$ & $\begin{array}{l}\text { Customer } \\
\text { increase for } \\
\text { farming } \\
\text { experience } \\
\text { service }\end{array}$ & $\begin{array}{l}\text { Customer } \\
\text { increase for } \\
\text { delivery } \\
\text { service }\end{array}$ & $\begin{array}{l}\text { Increased } \\
\text { production }\end{array}$ & $\begin{array}{c}\text { Rise of } \\
\text { product } \\
\text { price }\end{array}$ & $\begin{array}{c}\text { Change of } \\
\text { production } \\
\text { plan }\end{array}$ & Others \\
\hline & 32.3 & 41.9 & 16.1 & 3.2 & 3.2 & 29.0 & 16.1 & 9.7 & 6.5 \\
\hline \multirow{3}{*}{$\begin{array}{l}\text { Less } \\
\text { resilient } \\
\text { farms } \\
(n=19)\end{array}$} & \multicolumn{9}{|c|}{ Reasons for sales decrease (multiple answers) (\%) } \\
\hline & $\begin{array}{l}\text { Customer } \\
\text { decrease in } \\
\text { farmers } \\
\text { markets }\end{array}$ & $\begin{array}{c}\text { Sales } \\
\text { decrease } \\
\text { for } \\
\text { restaurants }\end{array}$ & $\begin{array}{c}\text { Sales } \\
\text { decrease } \\
\text { for school } \\
\text { meal }\end{array}$ & $\begin{array}{c}\text { Decrease of } \\
\text { off-farm } \\
\text { events }\end{array}$ & $\begin{array}{c}\text { Decrease of } \\
\text { on-farm } \\
\text { events }\end{array}$ & $\begin{array}{c}\text { Self- } \\
\text { quarantine }\end{array}$ & $\begin{array}{c}\text { Fall in } \\
\text { production } \\
\text { price }\end{array}$ & $\begin{array}{l}\text { Change of } \\
\text { production } \\
\text { plan }\end{array}$ & Others \\
\hline & 5.3 & 15.8 & 26.3 & 31.6 & 5.3 & 10.5 & 63.2 & 10.5 & 21.1 \\
\hline
\end{tabular}

Conversely, Table 2 demonstrates that "fall in production price" $(63.2 \%)$ is the most significant reason for decreasing sales of less resilient farms. According to consumer price statistics in Japan, the vegetable price in the October-to-December quarter in 2020 was much lower than that in 2019. However, the vegetable price in the April-September quarter in 2020 was higher than that in 2019. All urban farmers face the same market conditions. Consequently, less resilient farms could not absorb these price fluctuations by changing their strategies or marketing channels. Moreover, the Covid-19 pandemic directly affected the less resilient farms through "decrease of off-farm events" (31.6\%) and "sales decrease for school meal" (26.3\%).

If direct marketing is one of the resilience attributes of urban farmers, the question is whether this resilience capability is "persistence" or "adaptation". In our survey, the 
sample farmers were asked to give details regarding their new business models or management activities that they started in 2020 . However, $73 \%$ of the sample farmers never started additional businesses, and the differences among resilience types were not statistically significant $(p>0.10)$. Similarly, $62 \%$ of the sample farmers did not improve any farm management practices, and the differences among resilience types were not statistically significant $(p>0.10)$. In summary, even highly resilient farms seldom transformed their business models or farming practices; that is, they tried to exploit their existing management resources and marketing channels effectively. This "persistence" resilience capability is thought to be a characteristic of urban farmers.

As can be seen in Table 3, whereas $46.2 \%$ of the sales of the highly resilient farms fall between 3 and 10 million yen, 35.3\% of the sales of the less resilient farms are more than 10 million yen. This result means that the farm size of the highly resilient farms is not necessarily larger than that of the less resilient farmers; thus, farm size is not a decisive factor for farm resilience in urban areas.

Table 3. Distribution of sales in 2019 by resilience type.

\begin{tabular}{|c|c|c|c|c|c|c|c|c|c|}
\hline \multirow{2}{*}{$\begin{array}{c}\text { Short-Term } \\
\text { Resilience Type }\end{array}$} & \multicolumn{9}{|c|}{ Sales in Million Yen } \\
\hline & No Sales & $\begin{array}{c}\text { Less than } \\
0.49\end{array}$ & $\begin{array}{l}0.50- \\
0.99\end{array}$ & $\begin{array}{l}1.00- \\
1.99\end{array}$ & $\begin{array}{l}2.00- \\
2.99\end{array}$ & $\begin{array}{l}3.00- \\
4.99\end{array}$ & $\begin{array}{l}5.00- \\
9.99\end{array}$ & $\begin{array}{l}10.00- \\
19.99\end{array}$ & $\begin{array}{c}\text { More than } \\
20.00\end{array}$ \\
\hline & \multicolumn{9}{|c|}{$\%$ of farms } \\
\hline Highly resilient farms & 0.0 & 7.7 & 7.7 & 11.5 & 3.8 & 23.1 & 23.1 & 19.2 & 3.8 \\
\hline Less resilient farms & 0.0 & 5.9 & 11.8 & 0.0 & 17.6 & 5.9 & 23.5 & 23.5 & 11.8 \\
\hline Middle-resilient farms & 23.8 & 4.8 & 9.5 & 4.8 & 23.8 & 14.3 & 4.8 & 9.5 & 4.8 \\
\hline
\end{tabular}

Finally, Figure 11 demonstrates the direct effects of the Covid-19 pandemic on farming practices. In particular, $75.3 \%$ of the sample farmers did not practice infection prevention. Consequently, this pandemic did not change farming practices and drastically affected production.

nothing in particular

avoid the Three Cs by changing production plans reduce the number of persons who work at the same time stop using parttime workers and volunteers avoid the Three Cs by changing production environments others

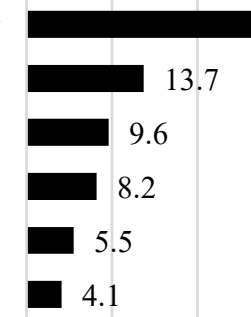

0 1020

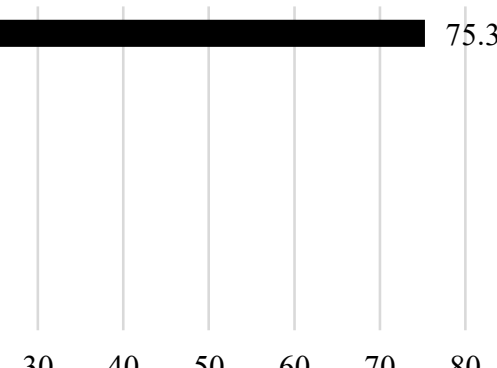
75.3

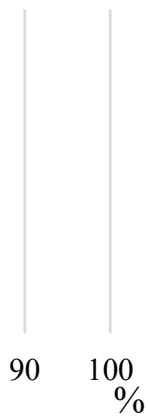

Figure 11. Percentage of farms that practice infection preventions (multiple answers). Note: Three Cs includes "crowded places", "close-contact settings", and "confined and enclosed spaces".

\subsection{Long-Term Farm Vision}

In this section, we discuss the relationship between short-term farm resilience and long-term farm vision. Table 4 illustrates the various visions of the sample farmers after this pandemic by resilience type. First, they answered the vision for "sales after Covid-19 pandemic (compared with sales in 2019)"; $35.1 \%$ of them anticipated increasing their sales. The important point is that the rate of farmers anticipating a decrease in sales is the lowest among the three categories. This means that urban farmers are not vulnerable to the Covid19 pandemic as a whole. However, according to the results of cross-tabulation between resilience type and this vision, the rate of less resilient farms who intended to decrease their sales is more than twice as much as that of the highly resilient farms. Conversely, highly resilient farms are more intended to increase their sales than others. Although these differences among resilience types are not statistically significant (Fisher's exact test: 
$p$ value $=0.59>0.10$ ), these results potentially indicate that farm resilience to the Covid-19 pandemic affects the medium-term farm intention.

Table 4. Cross-tabulation between resilience types and farm visions.

\begin{tabular}{|c|c|c|c|c|c|c|c|}
\hline & & \multicolumn{6}{|c|}{ Visions } \\
\hline & & \multicolumn{3}{|c|}{$\begin{array}{l}\text { Sales after Covid-19 Pandemic } \\
\text { (Compared with Sales in 2019) }\end{array}$} & \multicolumn{3}{|c|}{$\begin{array}{l}\text { Long-Term Farm Vision } \\
\text { (Farm Size in 2030) }\end{array}$} \\
\hline & & Increase & Decrease & Status Quo & Enlarge & Downsize & Status Quo \\
\hline \multicolumn{2}{|l|}{$\begin{array}{c}\text { Total } \\
(n=74)\end{array}$} & $35.1 \%$ & $8.1 \%$ & $56.8 \%$ & $43.2 \%$ & $12.2 \%$ & $44.6 \%$ \\
\hline $\begin{array}{l}\text { Highly resilient } \\
\text { farms } \\
(n=31)\end{array}$ & (A) & $41.9 \%$ & $6.5 \%$ & $51.6 \%$ & $61.3 \%$ & $3.2 \%$ & $35.5 \%$ \\
\hline $\begin{array}{l}\text { Less resilient farms } \\
\qquad(n=19)\end{array}$ & (B) & $26.3 \%$ & $15.8 \%$ & $57.9 \%$ & $36.8 \%$ & $10.5 \%$ & $52.6 \%$ \\
\hline $\begin{array}{c}\text { Middle-resilient } \\
\text { farms } \\
(n=24)\end{array}$ & (C) & $33.3 \%$ & $4.2 \%$ & $62.5 \%$ & $25.0 \%$ & $25.0 \%$ & $50.0 \%$ \\
\hline \multicolumn{2}{|c|}{ Fisher's exact test } & \multicolumn{3}{|c|}{$p$ value $=0.59>0.10$} & \multicolumn{3}{|c|}{$p$ value $=0.03<0.05$} \\
\hline \multicolumn{2}{|c|}{$\begin{array}{l}\text { Pairwise comparisons of } \\
\text { Wilcoxon rank sum test }\end{array}$} & & & & $\mathrm{A}>\mathrm{C}^{*}$ & $\mathrm{~A}<\mathrm{C}^{+}$ & \\
\hline
\end{tabular}

Note: $+p<0.1 ;{ }^{*} p<0.05$.

From a long-term perspective, $43.2 \%$ of the sample farmers have visions to enlarge their farm size by 2030 . Moreover, this rate increased to $61.3 \%$ for highly resilient farms. Fisher's exact test demonstrated statistically significant differences among resilient types ( $p$ value $=0.03<0.05)$, and pairwise comparisons of the Wilcoxon rank sum test revealed that at least the highly resilient farmers tended to develop their farms more than the middleresilient ones. These results suggest that farmers who demonstrated their bounce-forward resilience to the Covid-19 pandemic are more proactive in developing their farms in the long run. However, less resilient farmers are not necessarily the most pessimistic about their future.

This long-term farm vision is potentially related to the intention to preserve farmland or to make use of the multifunctionality of farmland. Table 5 shows the relationship between long-term farm vision and the farmer's intentions. Apparently, the farmers who hope for status quo have the strongest intentions to "designate their farmland as specified production green land" and "preserve all of their farmland after inheritance taxation". This suggests that farmers who are confident of their farmland stability intend to maintain their farm size.

Table 5. Cross-tabulation between farm size vision and long-term intentions.

\begin{tabular}{|c|c|c|c|c|c|c|}
\hline & & & \multicolumn{4}{|c|}{ Long-Term Intention to ... } \\
\hline & & & $\begin{array}{c}\text { Designate Their } \\
\text { Farmland } \\
\text { as Specified Production } \\
\text { Green Land }\end{array}$ & $\begin{array}{l}\text { Preserve Their } \\
\text { Farmland } \\
\text { after Inheritance } \\
\text { Taxation }\end{array}$ & $\begin{array}{c}\text { Designate their } \\
\text { Farmland as } \\
\text { Disaster Prevention } \\
\text { Farmland }\end{array}$ & $\begin{array}{l}\text { Rent Farmland } \\
\text { in the Future }\end{array}$ \\
\hline \multirow{3}{*}{$\begin{array}{l}\text { Farm size } \\
\text { in } 2030\end{array}$} & Enlarge & (A) & $82.1 \%$ & $59.4 \%$ & $70.0 \%$ & $28.1 \%$ \\
\hline & Downsize & (B) & $42.9 \%$ & $11.1 \%$ & $44.4 \%$ & $11.1 \%$ \\
\hline & Status quo & (C) & $90.6 \%$ & $72.7 \%$ & $65.6 \%$ & $12.1 \%$ \\
\hline \multicolumn{3}{|c|}{$\begin{array}{l}\text { Pairwise comparisons of } \\
\text { Wilcoxon rank sum test }\end{array}$} & $\mathrm{B}<\mathrm{C}^{* *}$ & $\mathrm{~A}>\mathrm{B}^{*}, \mathrm{C}>\mathrm{B}^{* *}$ & & \\
\hline
\end{tabular}

Note: ${ }^{*} p<0.05 ;{ }^{* *} p<0.01$. Specified production green land is tax-relief farmland under a strict development control in urban areas. Disaster prevention farmland is farmland that is used as evacuation sites in case of disaster. 
Furthermore, farmers who plan to downsize their farms in the future have the least intention to preserve farmland. This tendency is statistically significant; that is, long-term farm vision certainly affects the stability of farmland in UPA. Farmers who plan to enlarge their farms are characterized by strong intentions to "designate their farmland as disaster prevention farmland" and "rent farmland in the future". The former is related to the exploitation of the multifunctionality of urban farmland, and the latter is related to the preservation of farmland that is potentially abandoned in accordance with decreasing farmers. Consequently, the long-term farm visions of farmers are more than individual farms' decisions, and these visions also affect the long-term sustainability of UPA.

\subsection{Resilience Attributes}

In this section, the relationships between resilience attributes and resilience types are summarized. First, Table 6 shows the average scores of entrepreneurial orientation (EO) indicators by resilience type. To control the effects of the marketing channels that farmers mainly use on the extent of EO, the sample farms are divided into direct-marketing farms and mass-marketing farms. As seen in Table 6, the integrated EO score and individual indicators were higher in the highly resilient farms than in the less resilient farms. This tendency was observed for both marketing channels. However, whereas resilient directmarketing farms demonstrate proactiveness and risk-taking, resilient mass-marketing farms show innovativeness. This implies that to be resilient to the Covid-19 pandemic, the direct-marketing farmers had to compete with other farmers to obtain new customers, but the mass-marketing farmers had to produce better products and sell them in the markets to attract market participants.

Table 6. Average scores of entrepreneurial orientation indicators by resilience types.

\begin{tabular}{|c|c|c|c|c|c|c|c|c|c|}
\hline \multirow{3}{*}{$\begin{array}{c}\text { 1st } \\
\text { Channel }\end{array}$} & \multirow{3}{*}{$\begin{array}{c}\text { Resilience } \\
\text { Type }\end{array}$} & \multirow{3}{*}{$n$} & \multirow{3}{*}{ EO } & \multicolumn{6}{|c|}{ Breakdown } \\
\hline & & & & \multicolumn{2}{|c|}{ Innovativeness } & \multicolumn{2}{|c|}{ Proactiveness } & \multicolumn{2}{|c|}{ Risk Taking } \\
\hline & & & & $\begin{array}{l}\text { R\&D and } \\
\text { Innovation }\end{array}$ & $\begin{array}{c}\text { New } \\
\text { Product }\end{array}$ & $\begin{array}{l}\text { First- } \\
\text { Mover }\end{array}$ & $\begin{array}{l}\text { Competitive- } \\
\text { ness }\end{array}$ & $\begin{array}{c}\text { High-Risk } \\
\text { Project }\end{array}$ & $\begin{array}{c}\text { Bold Wide- } \\
\text { Ranging Acts }\end{array}$ \\
\hline \multirow{2}{*}{$\begin{array}{c}\text { Direct } \\
\text { marketing }\end{array}$} & $\begin{array}{c}\text { Highly } \\
\text { resilient farms }\end{array}$ & 21 & 18.4 & 3.3 & 3.1 & 3.6 & 2.9 & 2.6 & 2.9 \\
\hline & $\begin{array}{l}\text { Less } \\
\text { resilient farms }\end{array}$ & 9 & 15.2 & 3.4 & 2.7 & 2.7 & 2.1 & 2.1 & 2.2 \\
\hline \multirow{2}{*}{$\begin{array}{c}\text { Mass } \\
\text { marketing }\end{array}$} & $\begin{array}{l}\text { Highly } \\
\text { resilient farms }\end{array}$ & 7 & 19.3 & 3.6 & 3.4 & 4.1 & 2.4 & 2.6 & 3.1 \\
\hline & $\begin{array}{c}\text { Less } \\
\text { resilient farms }\end{array}$ & 9 & 17.4 & 2.9 & 2.8 & 3.4 & 2.8 & 2.4 & 3.1 \\
\hline \multicolumn{10}{|c|}{ Questionnaire statements } \\
\hline $\begin{array}{l}\text { R\&D and } \\
\text { innovation }\end{array}$ & \multicolumn{5}{|c|}{$\begin{array}{l}\text { I prefer a strong emphasis on the tried-and-trusted products } \\
\text { or services. }\end{array}$} & & \multicolumn{3}{|c|}{$\begin{array}{l}\text { I prefer a strong emphasis on } R \& D \text { and } \\
\text { innovative products or services. }\end{array}$} \\
\hline $\begin{array}{l}\text { New } \\
\text { product }\end{array}$ & \multicolumn{5}{|c|}{ I changed or newly marketed no products or services. } & & \multicolumn{3}{|c|}{$\begin{array}{l}\text { I changed or newly marketed many products } \\
\text { or services. }\end{array}$} \\
\hline $\begin{array}{l}\text { First- } \\
\text { mover }\end{array}$ & \multicolumn{5}{|c|}{$\begin{array}{l}\text { My farm is seldom the first to introduce new products, services, } \\
\text { management techniques, operating technologies, etc. }\end{array}$} & & \multicolumn{3}{|c|}{$\begin{array}{l}\text { My farm is very often the first to introduce new } \\
\text { products, services, management techniques, } \\
\text { operating technologies, etc. }\end{array}$} \\
\hline $\begin{array}{l}\text { Competitive- } \\
\text { ness }\end{array}$ & \multicolumn{5}{|c|}{ My farm adopts a less competitive approach. } & $123 \pm 0$ & \multicolumn{3}{|c|}{ My farm adopts a more competitive approach. } \\
\hline $\begin{array}{l}\text { High-risk } \\
\text { project }\end{array}$ & \multicolumn{5}{|c|}{ I have a strong preference for low-risk projects. } & & \multicolumn{3}{|c|}{ I have a strong preference for high-risk projects. } \\
\hline $\begin{array}{l}\text { Bold wide- } \\
\text { ranging } \\
\text { acts }\end{array}$ & \multicolumn{5}{|c|}{$\begin{array}{l}\text { Owing to the nature of the environment, it is best to act } \\
\text { cautiously to achieve farm's objectives. }\end{array}$} & & \multicolumn{3}{|c|}{$\begin{array}{l}\text { Owing to the nature of the environment, bold, } \\
\text { wide-ranging acts are necessary to achieve the } \\
\text { farm's objectives. }\end{array}$} \\
\hline
\end{tabular}

Note: EO (entrepreneurial orientation) is the sum of each breakdown indicator. The middle-resilient farms are omitted in the table. Farmers who use other first channels than direct marketing and mass marketing are also omitted. 
Second, according to Table 7, the social network score is also higher for highly resilient farms. The scores of "farmers in other areas", "distributors and retailers", and "retailers on website" seem to be common networks for the highly resilient farms of both marketing channels. This finding emphasises the importance of networks related to marketing channels to be resilient. Moreover, "local residents" is quite a helpful network for the resilient direct-marketing farms, and the networks of "CEO of other industries" are exploited by the resilient mass-marketing farms. Consequently, EO and social networks are expected to contribute to building farm resilience.

Table 7. Average scores of social network indicators by resilience type.

\begin{tabular}{|c|c|c|c|c|c|c|c|c|c|c|c|c|c|}
\hline \multirow[b]{2}{*}{$\begin{array}{c}1 \text { st } \\
\text { Channel }\end{array}$} & \multirow[b]{2}{*}{$\begin{array}{l}\text { Resilience } \\
\text { Type }\end{array}$} & \multirow[b]{2}{*}{$n$} & \multirow{2}{*}{$\begin{array}{l}\text { Social } \\
\text { Network } \\
\text { Score }\end{array}$} & \multicolumn{10}{|c|}{ Breakdown } \\
\hline & & & & $\begin{array}{c}\text { Local } \\
\text { Farmers }\end{array}$ & $\begin{array}{c}\text { Farmers } \\
\text { in Other } \\
\text { Areas }\end{array}$ & $\begin{array}{c}\text { Farmers' } \\
\text { Coopera- } \\
\text { tives }\end{array}$ & $\begin{array}{l}\text { Government, } \\
\text { Extension } \\
\text { Services }\end{array}$ & $\begin{array}{l}\text { Input } \\
\text { Traders }\end{array}$ & $\begin{array}{l}\text { Distributors } \\
\text { and } \\
\text { Retailers }\end{array}$ & $\begin{array}{c}\text { Retailers } \\
\text { on Website }\end{array}$ & $\begin{array}{c}\text { CEO of } \\
\text { other } \\
\text { Industries }\end{array}$ & $\begin{array}{c}\text { Local } \\
\text { Residents }\end{array}$ & Customers \\
\hline \multirow{2}{*}{$\begin{array}{c}\text { Direct } \\
\text { marketing }\end{array}$} & $\begin{array}{l}\text { Highly } \\
\text { resilient } \\
\text { farms }\end{array}$ & 21 & 29.5 & 2.9 & 2.7 & 3.2 & 2.6 & 2.9 & 2.7 & 2.8 & 2.8 & 3.5 & 3.4 \\
\hline & $\begin{array}{l}\text { Less } \\
\text { resilient } \\
\text { farms }\end{array}$ & 9 & 26.3 & 3.0 & 2.2 & 2.9 & 2.6 & 3.1 & 2.2 & 2.1 & 2.4 & 2.8 & 3.0 \\
\hline \multirow{2}{*}{$\begin{array}{c}\text { Mass } \\
\text { marketing }\end{array}$} & $\begin{array}{l}\text { Highly } \\
\text { resilient } \\
\text { farms }\end{array}$ & 7 & 32.1 & 3.3 & 2.7 & 3.3 & 3.1 & 3.1 & 3.4 & 3.0 & 3.3 & 3.3 & 3.6 \\
\hline & $\begin{array}{l}\text { Less } \\
\text { resilient } \\
\text { farms }\end{array}$ & 9 & 28.1 & 2.8 & 2.1 & 3.1 & 2.8 & 2.8 & 2.9 & 2.2 & 2.1 & 3.2 & 4.1 \\
\hline
\end{tabular}

Note: Social network score is the sum of each breakdown indicator. The participants are asked to score on "how helpful do you think each entity is" and answers are as follows: 5: greatly helpful, 4: helpful, 3: neither, 2: less helpful, and 1: never helpful. The middle-resilient farms are omitted in the table. Farmers who use other 1st channels than direct marketing and mass marketing are also omitted.

In addition, although management capabilities are not directly related to our hypotheses, Table 8 shows the relationship between management capabilities and resilience. There is no difference between the resilience types of direct-marketing farms in the integrated management capability score. This implies that overall management capability is not necessarily the determinant of farm resilience. However, resilient mass-marketing farms have comparatively high management capabilities, especially marketing and human resource management.

Table 8. Average scores of management capability indicators by resilience type.

\begin{tabular}{|c|c|c|c|c|c|c|c|}
\hline \multirow[b]{2}{*}{ 1st Channel } & \multirow[b]{2}{*}{$\begin{array}{l}\text { Resilience } \\
\text { Type }\end{array}$} & \multirow[b]{2}{*}{$n$} & \multirow[b]{2}{*}{$\begin{array}{c}\text { Management } \\
\text { Capability Score }\end{array}$} & \multicolumn{4}{|c|}{ Breakdown } \\
\hline & & & & Production & Accounting & Marketing & $\begin{array}{c}\text { Human } \\
\text { Resource } \\
\text { Managemen }\end{array}$ \\
\hline \multirow{2}{*}{$\begin{array}{c}\text { direct } \\
\text { marketing }\end{array}$} & $\begin{array}{c}\text { Highly } \\
\text { resilient farms }\end{array}$ & 21 & 11.7 & 3.1 & 3.0 & 2.9 & 2.7 \\
\hline & $\begin{array}{c}\text { Less } \\
\text { resilient farms }\end{array}$ & 9 & 11.1 & 3.2 & 2.8 & 2.4 & 2.7 \\
\hline \multirow{2}{*}{$\begin{array}{c}\text { mass } \\
\text { marketing }\end{array}$} & $\begin{array}{l}\text { Highly } \\
\text { resilient farms }\end{array}$ & 7 & 13.3 & 3.6 & 2.9 & 3.7 & 3.1 \\
\hline & $\begin{array}{c}\text { Less } \\
\text { resilient farms }\end{array}$ & 9 & 11.8 & 3.7 & 2.9 & 2.9 & 2.3 \\
\hline
\end{tabular}

Note: Management capability score is the sum of each breakdown indicator. The participants are asked to score on "how competent is your farm on each management compared to other farms" and answers are below: 5 : greatly competent, 4: competent, 3: neither, 2: less competent, and 1: never competent. The middle-resilient farms are omitted in the table. Farmers who use other 1st channels than direct marketing and mass marketing are also omitted.

The CSR activities of urban farmers are strong predictors of farm sustainability. Table 9 demonstrates the scores of the social and environmental sustainability index (SESI) and its indicators. Most importantly, the SESI of highly resilient direct-marketing farms is lower than that of less resilient direct-marketing farms. This tendency was observed for both social and environmental sustainability indicators. Conversely, highly resilient farms that 
sell to the mass markets particularly engage in environmental CSR activities. Table 10 describes the statistical relationships between variables. The SESI negatively correlates with the direct marketing dummy but positively correlates with the management capability score. As a result, mass-marketing farms are more concerned with CSR activities; moreover, those with sufficient management capabilities demonstrate both resilience and sustainability.

Table 9. Average scores of social and environmental sustainability index of by resilience type.

\begin{tabular}{|c|c|c|c|c|c|c|c|c|c|c|c|}
\hline \multirow[b]{4}{*}{ 1st Channel } & \multirow{4}{*}{$\begin{array}{l}\text { Resilience } \\
\text { Type }\end{array}$} & \multirow{4}{*}{$n$} & \multirow{4}{*}{$\begin{array}{c}\text { Social and } \\
\text { Environmental } \\
\text { Sustainability } \\
\text { Index } \\
\text { (SESI) }\end{array}$} & \multicolumn{8}{|c|}{ Breakdown (My farm tries to $\ldots$ ) } \\
\hline & & & & \multicolumn{6}{|c|}{ Social } & \multirow{2}{*}{\multicolumn{2}{|c|}{ Environmental }} \\
\hline & & & & & External & & & Internal & & & \\
\hline & & & & $\begin{array}{l}\text { Promote } \\
\text { Understanding } \\
\text { of Agriculture } \\
\text { and Food }\end{array}$ & $\begin{array}{l}\text { Promote Food } \\
\text { Safety and } \\
\text { Traceability }\end{array}$ & $\begin{array}{l}\text { Participate in } \\
\text { Local } \\
\text { Activities }\end{array}$ & $\begin{array}{l}\text { Improve } \\
\text { Working En- } \\
\text { vironments }\end{array}$ & $\begin{array}{c}\text { Consider } \\
\text { Employees' } \\
\text { Mental } \\
\text { Health }\end{array}$ & $\begin{array}{c}\text { Promote } \\
\text { the Employees' } \\
\text { Participation in } \\
\text { Management }\end{array}$ & $\begin{array}{c}\text { Improve } \\
\text { Agricultural } \\
\text { Landscape }\end{array}$ & $\begin{array}{l}\text { Reduce the } \\
\text { Usage of } \\
\text { Chemical } \\
\text { Fertilizer and } \\
\text { Pesticide }\end{array}$ \\
\hline \multirow{2}{*}{$\begin{array}{c}\text { Direct } \\
\text { marketing }\end{array}$} & $\begin{array}{l}\text { Highly resilient } \\
\text { farms }\end{array}$ & 21 & 13.7 & 2.0 & 1.6 & 2.0 & 1.8 & 1.4 & 1.4 & 1.7 & 1.8 \\
\hline & $\begin{array}{l}\text { Less resilient } \\
\text { farms }\end{array}$ & 9 & 15.1 & 2.0 & 1.7 & 2.1 & 1.9 & 1.7 & 1.7 & 2.0 & 2.1 \\
\hline \multirow{2}{*}{$\begin{array}{c}\text { Mass } \\
\text { marketing }\end{array}$} & $\begin{array}{l}\text { Highly resilient } \\
\text { farms }\end{array}$ & 7 & 17.9 & 2.3 & 2.4 & 2.4 & 2.1 & 2.0 & 2.0 & 2.3 & 2.3 \\
\hline & $\begin{array}{l}\text { Less resilient } \\
\text { farms }\end{array}$ & 9 & 15.9 & 2.2 & 2.1 & 2.2 & 2.2 & 1.8 & 1.8 & 1.7 & 1.9 \\
\hline
\end{tabular}

Note: SESI is the sum of each breakdown indicator. The participants are asked to score on "how proactively do your farm engage in each activity compared to other farms" and answers are as follows: 3: more proactive than other farmers, 2: the same as other farms, and 1: not at all proactive. The middle-resilient farms are omitted in the table. Farmers who use other 1st channels than direct marketing and mass marketing are also omitted.

Table 10. Correlation between SESI and other variables.

\begin{tabular}{|c|c|c|c|c|c|}
\hline & SESI & Direct Marketing & $\begin{array}{c}\text { Entrepreneurial } \\
\text { Orientation }\end{array}$ & Networking & $\begin{array}{c}\text { Management } \\
\text { Capability }\end{array}$ \\
\hline $\begin{array}{l}\text { Direct marketing } \\
\text { dummy }\end{array}$ & $-0.33^{* *}$ & 1.00 & & & \\
\hline $\begin{array}{c}\text { Entrepreneurial } \\
\text { orientation }\end{array}$ & 0.19 & -0.13 & 1.00 & & \\
\hline Networking & $0.22^{+}$ & -0.03 & -0.08 & 1.00 & \\
\hline $\begin{array}{l}\text { Management } \\
\text { capability }\end{array}$ & $0.35^{* *}$ & $-0.26^{*}$ & 0.27 * & 0.08 & 1.00 \\
\hline
\end{tabular}

Note: $+p<0.1 ;{ }^{*} p<0.05 ; * *<0.01$; the correlations between direct marketing dummy and other variables are estimated with Spearman's rank correlation. Other correlations are estimated with Pearson's correlation.

\subsection{Regression Analysis}

Finally, Table 11 shows the results of the regression analyses on resilience types, SESI, and long-term farm vision. The goodness of fit of these three models was sufficient to interpret them. First, the estimation of the ordinal logit model with the resilience types as a dependent variable reveals that the direct marketing dummy, EO, and social network score have statistically significant positive effects. The positive coefficients of the ordinal logit model mean that the higher the variables are, the higher the probability that the sample farms belong to the highly resilient farms. Consequently, these resilience attributes certainly contribute to building the resilience of urban farmers to the Covid-19 pandemic. In addition, farm size (sales and farmland) and population density had little effect on farm resilience. 
Table 11. Regression analyses on short-term resilience type, SESI, and long-term farm vision.

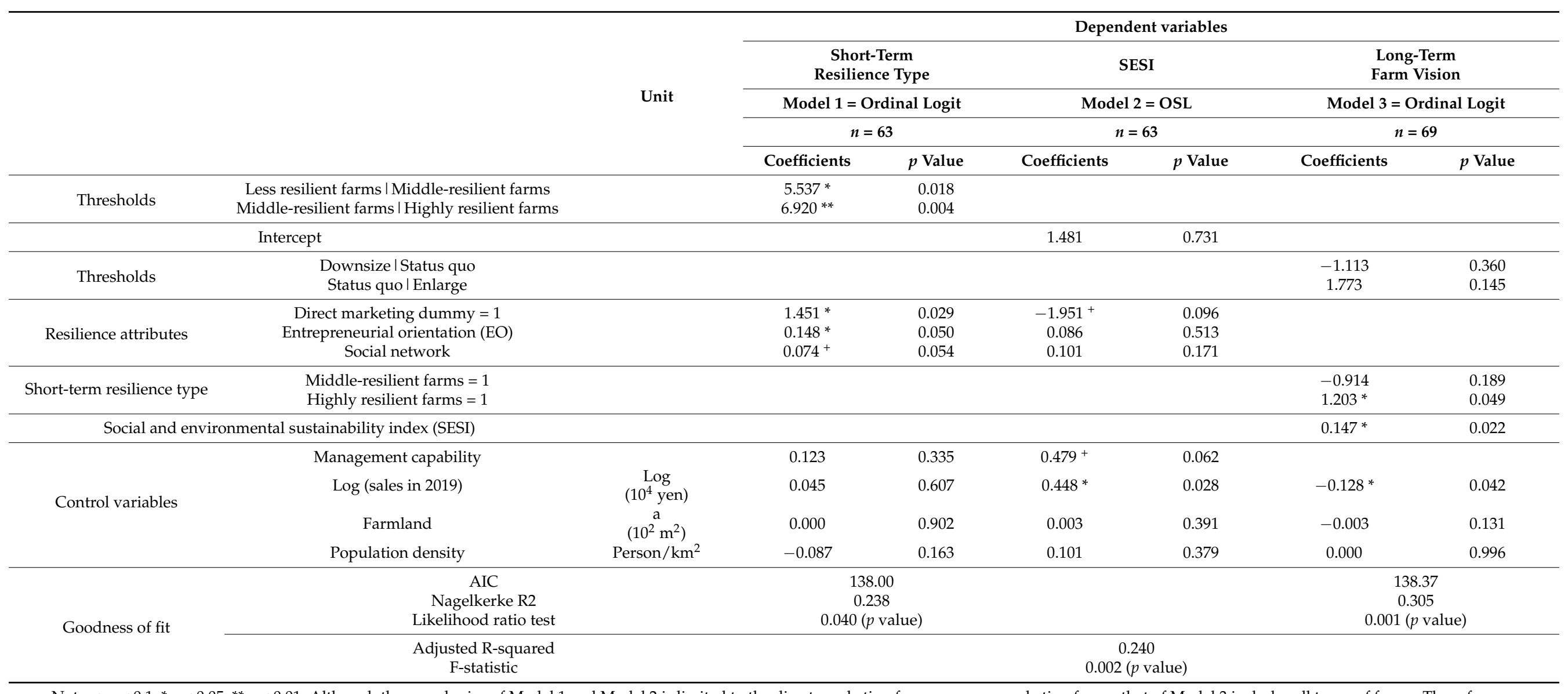

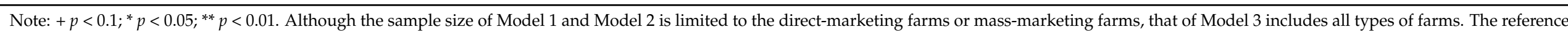
of direct marketing dummy is "mass marketing farms", and the reference of short-term resilience is "less resilient farms". 
Second, as seen in the results of the SESI OLS model, only the management capability score and the logarithm of sales in 2019 have statistically significant positive effects on SESI. By contrast, the direct marketing dummy negatively affects it. These facts imply that relatively large farms capable of various aspects of farm management can continue their sustainable activities. This sustainability condition is completely different from that of farm resilience.

Finally, the ordinal logit model that employs long-term farm vision as a dependent variable demonstrates that the coefficients of the ordinal variables of the resilient types and SESI are significantly positive. This means that compared to the less resilient farms, the probability of the highly resilient farms belonging to the "enlarge" category of long-term farm vision is higher. Therefore, both the resilience to the Covid-19 pandemic and the sustainable activities strengthen the farmers' intention to enlarge their farms in 10 years. As a result, the complementary functions of resilience and sustainability for urban farmers are evidenced by this model.

\section{Discussion}

Based on the aforementioned results, we discuss the characteristics of the farm resilience of urban farmers in Tokyo during the Covid-19 pandemic. First of all, a number of farms demonstrated their resilience that was considered as "persistence" in accordance with Darnhofer's categorization [10]. They exploited their direct marketing channels and reallocated their resources to these channels. This farm diversification strategy of direct marketing has been established by urban farmers in Tokyo over a long period of time. The Census of Agriculture and Forestry indicates that the rate of direct-marketing farms in Tokyo (55\%) is much higher than that in Japan (17\%); in addition, the average annual sales of the farmers' market in Tokyo (2.86 million yen) and the number of farmers' market per farmer (0.11) ranks top in the nation. This precondition of urban agriculture in Tokyo enabled more than half of the sample farms to increase their sales during the specific social and economic challenges caused by the strict restriction of the movement of people.

While the business model of urban agriculture fits with the changing consumer demands for local food, entrepreneurship, and social networks play important roles in building farm resilience. Even if the urban farmers engaged in direct marketing, the farmers lacking these resilience attributes seemed to have difficulty in sufficiently exploiting business opportunities. More importantly, some farmers with those attributes who mainly sold their products to mass markets, such as wholesale markets or retailers, demonstrated sufficient resilience.

Enhancing the resilience of mass-marketing farms is an urgent problem in maintaining a diversity of producers in an urban farming system as a whole. Diversity is a resilience attribute that should be equipped with farming systems [11]. Nera et al. insisted that the lack of diversity in the hazelnut industry in Italy is an obstacle to transformability building [18]. Moreover, many of the stakeholders in farming systems tend to disregard this transformability building [56]. Our study suggests that public support for enhancing farmers' entrepreneurship and social networks contributes to the survival of farmers whose marketing channels do not fit the changing consumer demand, thus resulting in the preservation of the diversity of urban farms after the Covid-19 pandemic.

The workshop study indicates that the measures that farmers think are effective in building adaptability and transformability are "peer-to-peer learning", "consulting non-farming experts", "experimentation", and "seeking out new contacts or knowledge networks" [40]. These insights are key to developing farmers' entrepreneurship and social networks. These fundamental resilience attributes are important for the general resilience of farms not only to the Covid-19 pandemic but also to various potential challenges in the future.

However, this study does not include the important factors that affect the resilience of urban farms to the Covid-19 pandemic such as the diversity of marketing channels, produce, and production methods of farms. When the pandemic forces the farms to change 
marketing channels emergently, the farms that have diverse marketing channels can easily adapt to the situation. On the other hand, if the farms produce only a few varieties of produce, it is difficult for them to satisfy the consumer demand of other channels. The same applies to the production methods such as environmentally friendly practices. These diversities are important not only for risk reduction but also for the dynamic transformation of farms.

Second, this study indicated that the short-term resilience of urban farms to the Covid-19 pandemic potentially affected long-term farm development. In other words, the influence of the Covid-19 pandemic on UPA has remained for decades. The case study in China suggested that the incidence rate of Covid-19 and village lockdown did not have any influence on the long-term expectations of farmers [3]. Thus, to preserve urban farmland and to exploit the multifunctionality of urban agriculture, successful farm behaviors to shocks are more important than the effects of the Covid-19 pandemic, that is, the support to enhance the short-term resilience of the urban farms is worth more than the short-term profit of the farms. To stimulate demand for local food consumption, an effective support measure is to promote farmers to invest more in the improvement of direct marketing services. On the other hand, it takes a relatively long time for farmers to build their entrepreneurial nature and social networks. Policymakers have to prepare advanced programs to promote farmers' entrepreneurship or to prepare opportunities for farmers to build networks with various stakeholders.

Short supply chains such as direct marketing was a specific resilience attribute to the Covid-19 pandemic because the consumers' demands for local marketing channels were unexpectedly increased by this pandemic. On the other hand, the attributes such as entrepreneurship and social networks can be considered to be more general ones. This is because these attributes are deeply related to farmers' decision-making processes for opportunity exploitation. Then, entrepreneurial farmers who have sufficient social networks may be resilient to any other shocks or stresses such as climate change, price fluctuation, and natural disasters.

Third, the sustainable activities of urban farms are independently associated with longterm farm development. This finding indicates the complementarity between resilience and sustainability $[17,18]$. The considerations for various stakeholders, including the natural environment in normal times (sustainability) and the flexible persistence or adaptability to shocks in emergencies (resilience) are indispensable to each other. In this respect, this study shows that the direct-marketing farmers are relatively reluctant to perform socially and environmentally sustainable activities. This fact implies that alternative business models that pay more attention on sustainability are required such as community-oriented farming experience services or community-supported agriculture based on environmentally friendly production methods.

This study also suggests that management capabilities are important factors that effectively promote the CSR activities of urban farms. Eventually, both the entrepreneurial and managerial aspects of farmers contribute to long-term farm development, thus resulting in the sustainability of the urban farming system. A quantitative study in Japan revealed that urban farmers who are equipped with those two aspects accounted for only $10 \%$ of the sample farmers [8]. This fact compels researchers and policymakers to realize that considerable effort is required to achieve the sustainable development of urban agriculture.

\section{Conclusions}

This study aims to reveal the conditions for farm resilience to the Covid-19 pandemic in 2020 and the relationship between short-term farm resilience and long-term farm development. The results are as follows. First, more than half of the sample farms demonstrated resilience to shock. This resilience was called "persistence". Second, short-term farm resilience and sustainable farm activities certainly contributed to improving intentions for farm development. Third, the most important resilience attributes were direct marketing strategy, entrepreneurship, and social networks. 
We discussed that the business model of direct marketing that has been historically established by urban farmers is critically important to build specific resilience. However, to enhance general resilience, support for the survival of farmers who use marketing channels other than direct marketing is required to maintain the diversity of urban farming systems. In addition, the management capabilities that supply the farmers with a base for sustainable activities should also be improved.

Finally, the desirable research directions are described as follows: as the Covid-19 pandemic is not fully contained at present, continuous research is needed to confirm that our hypotheses are valid even if the social and economic conditions are changing. In particular, the future of agritourism, such as farming experience, significantly affects the long-term development of UPA. Second, the sample of this study is biased to large-sales farms compared to the population of farms in Tokyo. It means that the much more small farms in Tokyo might have been negatively affected by the Covid-19 pandemic. Further research on smaller farms is required. Third, although this study only focused on the persistence aspect of resilience, most previous studies indicated that the adaptation or transformability of farms is crucially important. Gathering the cases in which farmers try to drastically transform their business model to exploit the opportunities caused by the Covid-19 pandemic contributes to the further theoretical development of farm resilience.

Author Contributions: Conceptualization, S.Y.; Methodology, S.Y.; Software, S.Y.; Validation, H.Y., Formal Analysis, S.Y.; Investigation, S.Y.; Resources, S.Y.; Data Curation, S.Y. and H.Y.; WritingOriginal Draft Preparation, S.Y.; Writing-Review and Editing, S.Y.; Supervision, H.Y.; Project Administration, S.Y. and H.Y.; Funding Acquisition, H.Y. All authors have read and agreed to the published version of the manuscript.

Funding: This research was funded by the Japan Society for the Promotion of Science (grant number 19092455).

Data Availability Statement: Data sharing is not applicable to this article. The data used for this study were collected from farmers who require confidential use of these data.

Conflicts of Interest: The authors declare no conflict of interest. The sponsors had no role in the design, execution, interpretation, or writing of the study.

\section{References}

1. Savary, S.; Akter, S.; Almekinders, C.; Harris, J.; Korsten, L.; Rötter, R.; Waddington, S.; Watson, D. Mapping Disruption and resilience mechanisms in food systems. Food Secur. 2020, 12, 695-717. [CrossRef]

2. Altieri, M.A.; Nicholls, C.I. Agroecology and the reconstruction of a post-COVID-19 agriculture. J. Peasant. Stud. 2020, 47, 881-898. [CrossRef]

3. Du, Z.; Lai, X.; Long, W.; Gao, L. The short-and long-term impacts of the COVID-19 pandemic on family farms in China-Evidence from a survey of 2324 farms. J. Integr. Agric. 2020, 19, 2877-2890. [CrossRef]

4. Mastronardi, L.; Cavallo, A.; Romagnoli, L. Diversified farms facing the Covid-19 pandemic: First signals from Italian case studies. Sustainability 2020, 12, 5709. [CrossRef]

5. Chang, H.-H.; Mishra, A.K.; Lee, T.-H. A Supply-side analysis of agritourism: Evidence from farm-level agriculture census data in Taiwan. Aust. J. Agric. Resour. Econ. 2019, 63, 521-548. [CrossRef]

6. Lange, A.; Piorr, A.; Siebert, R.; Zasada, I. Spatial differentiation of farm diversification: How rural attractiveness and vicinity to cities determine farm households' response to the CAP. Land Use Policy 2013, 31, 136-144. [CrossRef]

7. Pölling, B.; Mergenthaler, M. The location matters: Determinants for "deepening" and "broadening" diversification strategies in Ruhr metropolis' urban farming. Sustainability 2017, 9, 1168. [CrossRef]

8. Yoshida, S.; Yagi, H.; Kiminami, A.; Garrod, G. Farm diversification and sustainability of multifunctional peri-urban agriculture: Entrepreneurial attributes of advanced diversification in Japan. Sustainability 2019, 11, 2887. [CrossRef]

9. Walker, B.; Holling, C.S.; Carpenter, S.R.; Kinzig, A. Resilience, adaptability and transformability in social-ecological systems. Ecol. Soc. 2004, 9. [CrossRef]

10. Darnhofer, I.; Fairweather, J.; Moller, H. Assessing a farm's sustainability: Insights from resilience thinking. Int. J. Agric. Sustain. 2010, 8, 186-198. [CrossRef]

11. Meuwissen, M.P.M.; Paas, W.H.; Slijper, T.; Coopmans, I.; Ciechomska, A.; Lievens, E.; Deckers, J.; Vroege, W.; Mathijs, E.; Kopainsky, B.; et al. Report on Resilience Framework for EU Agriculture: Sustainable and Resilient EU Farming Systems (SureFarm) Project Report, Work Package D1. 1; Wageningen University \& Research: Wageningen, The Netherlands, 2018.

12. Darnhofer, I. Resilience and why it matters for farm management. Eur. Rev. Agric. Econ. 2014, 41, 461-484. [CrossRef] 
13. Yokohari, M.; Takeuchi, K.; Watanabe, T.; Yokota, S. Beyond greenbelts and zoning: A new planning concept for the environment of Asian mega-cities. In Urban Ecology; Springer: Berlin/Heidelberg, Germany, 2008; pp. 783-796.

14. Kurita, H.; Yokohari, M.; Bolthouse, J. The potential of intra-regional supply and demand of agricultural products in an urban fringe area: A case study of the Kanto Plain, Japan. Geogr. Tidsskr. J. Geogr. 2009, 109, 147-159. [CrossRef]

15. Yoshida, S. Effects of urbanization on farmland size and diversified farm activities in Japan: An analysis based on the land parcel database. Land 2020, 9, 315. [CrossRef]

16. Bryant, C.R.; Johnston, T.R.R. Agriculture in the City's Countryside; Belhaven Press: London, UK, 1992.

17. Reidsma, P.; Paas, W.H.; Accatino, F.; Appel, F.; Black, J.; Bijttebier, J.; Gavrilescu, C.; Kopainsky, B.; Krupin, V.; ManevskaTasevska, G.; et al. D5. 6 Impacts of Improved Strategies and Policy Options on the Resilience of Farming Systems across the EU; Swedish University of Agricultural Sciences: Uppsala, Sweden, 2020.

18. Nera, E.; Paas, W.; Reidsma, P.; Paolini, G.; Antonioli, F.; Severini, S. Assessing the resilience and sustainability of a hazelnut farming system in Central Italy with a participatory approach. Sustainability 2020, 12, 343. [CrossRef]

19. Santo, R.; Palmer, A.; Kim, B. Vacant Lots to Vibrant Plots: A Review of the Benefits and Limitations of Urban Agriculture; John Hopkins Center for a Livable Future: Baltimore, MD, USA, 2016.

20. Nicholls, E.; Ely, A.; Birkin, L.; Basu, P.; Goulson, D. The contribution of small-scale food production in urban areas to the sustainable development goals: A review and case study. Sustain. Sci. 2020, 15, 1585-1599. [CrossRef]

21. Teitel-Payne, R.; Kuhns, J.; Nasr, J. Indicators for Urban Agriculture in Toronto: A Scoping Analysis; Toronto Urban Grow: Toronto, ON, Canada, 2016.

22. Clerino, P.; Fargue-Lelièvre, A. Formalizing objectives and criteria for urban agriculture sustainability with a participatory approach. Sustainability 2020, 12, 7503. [CrossRef]

23. Lovell, S.T. Multifunctional urban agriculture for sustainable land use planning in the United States. Sustainability 2010, 2, 2499-2522. [CrossRef]

24. Piorr, A.; Zasada, I.; Doernberg, A.; Zoll, F.; Ramme, W. Research for AGRI Committee-Urban and Peri-Urban Agriculture in the EU; European Parliament: Brussels, Belgium, 2018.

25. Azunre, G.A.; Amponsah, O.; Peprah, C.; Takyi, S.A.; Braimah, I. A review of the role of urban agriculture in the sustainable city discourse. Cities 2019, 93, 104-119. [CrossRef]

26. Gulyas, B.Z.; Edmondson, J.L. Increasing city resilience through urban agriculture: Challenges and solutions in the Global North. Sustainability 2021, 13, 1465. [CrossRef]

27. Sioen, G.B.; Terada, T.; Sekiyama, M.; Yokohari, M. Resilience with mixed agricultural and urban land uses in Tokyo, Japan. Sustainability 2018, 10, 435. [CrossRef]

28. Ikejima, Y. Measuring Elderly people's food access in urban food environments: The potential benefits of urban agriculture. Int. J. Sociol. Agric. Food 2019, 25, 21-41.

29. Pulighe, G.; Lupia, F. Multitemporal geospatial evaluation of urban agriculture and (non)-sustainable food self-provisioning in Milan, Italy. Sustainability 2019, 11, 1846. [CrossRef]

30. Guitart, D.; Pickering, C.; Byrne, J. Past results and future directions in urban community gardens research. Urban For. Urban Green. 2012, 11, 364-373. [CrossRef]

31. Litt, J.S.; Schmiege, S.J.; Hale, J.W.; Buchenau, M.; Sancar, F. Exploring ecological, emotional and social levers of self-rated health for urban gardeners and non-gardeners: A path analysis. Soc. Sci. Med. 2015, 144, 1-8. [CrossRef] [PubMed]

32. Litt, J.; Soobader, M.-J.; Turbin, M.S.; Hale, J.W.; Buchenau, M.; Marshall, J.A. The influence of social involvement, neighborhood aesthetics, and community garden participation on fruit and vegetable consumption. Am. J. Public Health 2011, 101, 1466-1473. [CrossRef] [PubMed]

33. Barton, J.; Pretty, J. What is the best dose of nature and green exercise for improving mental health? A multi-study analysis. Environ. Sci. Technol. 2010, 44, 3947-3955. [CrossRef] [PubMed]

34. van den Berg, A.E.; van Winsum-Westra, M.; de Vries, S.; van Dillen, S.M.E. Allotment gardening and health: A comparative survey among allotment gardeners and their neighbors without an allotment. Environ. Health 2010, 9, 74. [CrossRef]

35. Soga, M.; Cox, D.T.C.; Yamaura, Y.; Gaston, K.J.; Kurisu, K.; Hanaki, K. Health benefits of urban allotment gardening: Improved physical and psychological well-being and social integration. Int. J. Environ. Res. Public Health 2017, 14, 71. [CrossRef]

36. Harada, K.; Hino, K.; Iida, A.; Yamazaki, T.; Usui, H.; Asami, Y.; Yokohari, M. How does urban farming benefit participants' health? A case study of allotments and experience farms in Tokyo. Int. J. Environ. Res. Public Health 2021, 18, 542. [CrossRef]

37. Folke, C.; Carpenter, S.R.; Walker, B.; Scheffer, M.; Chapin, T.; Rockström, J. Resilience thinking: Integrating resilience, adaptability and transformability. Ecol. Soc. 2010, 15, 20. [CrossRef]

38. Darnhofer, I.; Strauss, A. Resilience of family farms: Understanding the trade-offs linked to diversification. In Proceedings of the 11th European IFSA Symposium-Farming Systems Facing Global Challenges: Capacities and Strategies, Berlin, Germany, 1-4 April 2014; pp. 1-4.

39. Darnhofer, I.; Strauss, A. Organic farming and resilience. Case Study Rep. Austria. Rethink. Proj. 2015. Available online: http: / / citeseerx.ist.psu.edu/viewdoc / download;jsessionid=30FE849D2547E43EEB586E60FC04F727?doi=10.1.1.705.747 $0 \&$ rep=rep1\&type $=$ pdf (accessed on 12 April 2021). 
40. Spiegel, A.; Soriano, B.; de Mey, Y.; Slijper, T.; Urquhart, J.; Bardají, I.; Vigani, M.; Severini, S.; Meuwissen, M. Risk Management and Its Role in Enhancing Perceived Resilience Capacities of Farms and Farming Systems in Europe; Wiley Online Library: Hoboken, NJ, USA, 2020.

41. Shane, S.; Venkataraman, S. The promise of entrepreneurship as a field of research. Acad. Manag. Rev. 2000, 25, 217-226. [CrossRef]

42. Soininen, J.; Martikainen, M.; Puumalainen, K.; Kyläheiko, K. Entrepreneurial orientation: Growth and profitability of Finnish small-and medium-sized enterprises. Int. J. Prod. Econ. 2012, 140, 614-621. [CrossRef]

43. Zahra, S.A.; Covin, J.G. Contextual influences on the corporate entrepreneurship-performance relationship: A longitudinal analysis. J. Bus. Ventur. 1995, 10, 43-58. [CrossRef]

44. Gellynck, X.; Cárdenas, J.; Pieniak, Z.; Verbeke, W. Association between innovative entrepreneurial orientation, absorptive capacity, and farm business performance. Agribusiness 2015, 31, 91-106. [CrossRef]

45. Micheels, E.T.; Boecker, A. Competitive strategies among Ontario farms marketing direct to consumers. Agric. Food Econ. 2017, 5, 1-23. [CrossRef]

46. Tang, G.; Chen, Y.; Jin, J. Entrepreneurial orientation and innovation performance: Roles of strategic HRM and technical turbulence. Asia Pac. J. Hum. Resour. 2015, 53, 163-184. [CrossRef]

47. Zhang, J.A.; Edgar, F.; Geare, A.; O'Kane, C. The interactive effects of entrepreneurial orientation and capability-based HRM on firm performance: The mediating role of innovation ambidexterity. Ind. Mark. Manag. 2016, 59, 131-143. [CrossRef]

48. Chen, Y.-C.; Li, P.-C.; Evans, K.R. Effects of interaction and entrepreneurial orientation on organizational performance: Insights into market driven and market driving. Ind. Mark. Manag. 2012, 41, 1019-1034. [CrossRef]

49. Berkes, F. Understanding uncertainty and reducing vulnerability: Lessons from resilience thinking. Nat. Hazards 2007, 41, 283-295. [CrossRef]

50. Soriano, B.; Bardaji, I.; Bertolozzi, D.; San Martín, C.; Spiegel, A.; Slijper, T.; Meuwissen, M.; Rommel, J.; Hansson, H.; Severini, S.; et al. D 2.6 Report on State and Outlook for Risk Management in EU Agriculture; Swedish University of Agricultural Sciences: Uppsala, Sweden, 2020.

51. Jack, S.L.; Anderson, A.R. The effects of embeddedness on the entrepreneurial process. J. Bus. Ventur. 2002, 17, 467-487. [CrossRef]

52. McKeever, E.; Jack, S.; Anderson, A. Embedded entrepreneurship in the creative re-construction of place. J. Bus. Ventur. 2015, 30, 50-65. [CrossRef]

53. Akgün, A.A.; Nijkamp, P.; Baycan, T.; Brons, M. Embeddedness of entrepreneurs in rural areas: A comparative rough set data analysis. Tijdschr. Econ. Soc. Geogr. 2010, 101, 538-553. [CrossRef]

54. Blundel, R. Network evolution and the growth of artisanal firms: A tale of two regional cheese makers. Entrep. Reg. Dev. 2002, 14, 1-30. [CrossRef]

55. Stam, W.; Elfring, T. Entrepreneurial orientation and new venture performance: The moderating role of intra-and extraindustry social capital. Acad. Manag. J. 2008, 51,97-111. [CrossRef]

56. Meuwissen, M.P.M.; Feindt, P.H.; Midmore, P.; Wauters, E.; Finger, R.; Appel, F.; Spiegel, A.; Mathijs, E.; Termeer, K.J.A.M.; Balmann, A.; et al. The Struggle of Farming Systems in Europe: Looking for Explanations through the Lens of Resilience; Wiley Online Library: Hoboken, NJ, USA, 2020.

57. Meuwissen, M.P.M.; Feindt, P.H.; Spiegel, A.; Termeer, C.J.A.M.; Mathijs, E.; de Mey, Y.; Finger, R.; Balmann, A.; Wauters, E.; Urquhart, J.; et al. A framework to assess the resilience of farming systems. Agric. Syst. 2019, 176, 102656. [CrossRef]

58. Miller, D. The correlates of entrepreneurship in three types of firms. Manag. Sci. 1983, 29, 770-791. [CrossRef]

59. Covin, J.G.; Slevin, D.P. Strategic management of small firms in hostile and benign environments. Strateg. Manag. J. 1989, 10, 75-87. [CrossRef]

60. McWilliams, A.; Siegel, D. Corporate social responsibility: A theory of the firm perspective. Acad. Manag. Rev. 2001, 26, 117-127. [CrossRef]

61. Ramachandran, V. Strategic corporate social responsibility: A 'dynamic capabilities' perspective. Corp. Soc. Responsib. Environ. Manag. 2011, 18, 285-293. [CrossRef]

62. Lebacq, T.; Baret, P.V.; Stilmant, D. Sustainability indicators for livestock farming. A review. Agron. Sustain. Dev. 2013, 33, 311-327. [CrossRef]

63. Meul, M.; van Passel, S.; Nevens, F.; Dessein, J.; Rogge, E.; Mulier, A.; van Hauwermeiren, A. MOTIFS: A monitoring tool for integrated farm sustainability. Agron. Sustain. Dev. 2008, 28, 321-332. [CrossRef]

64. Van Calker, K.J.; Berentsen, P.B.M.; Giesen, G.W.J.; Huirne, R.B.M. Identifying and ranking attributes that determine sustainability in Dutch dairy farming. Agric. Hum. Values 2005, 22, 53-63. [CrossRef] 